\title{
The Transformation of International TaX
}

\author{
By Ruth Mason
}

\section{ABSTRACT}

The recession of 2008 precipitated a political crisis that motivated an unprecedented international project to curb corporate tax dodging. This Article argues, contrary to dominant scholarly views, that this effort transformed international tax — changing its participants, agenda, institutions, norms, and even its legal forms. Perhaps most important, efforts to close corporate tax loopholes widened a rift over revenues that threatens a hundred-year-old tax treaty framework. This Article identifies and critically evaluates these changes.

\section{INTRODUCTION}

Professors like to joke on the first day of international tax class that "there's no such thing as international tax." Sadly, like most tax jokes, understanding it requires technical explanation and, even then, it is not funny. The joke relies on the observation that tax systems are creatures of national law. So, when we study "international tax" in U.S. law schools, we study how the United States taxes the foreign income of Americans, and we study how the United States taxes foreigners when they earn income in the United States. The implicit premise of the joke is that each state makes its tax law independently of other states. Increasingly, this joke is not only not funny; it is also not true.

This Article discusses the G20/Organisation for Economic Co-operation and Development (OECD) Base Erosion and Profit Shifting (BEPS) Project, a multilateral effort to combat corporate tax avoidance. Academics have harshly criticized BEPS, conceiving of it as a mere technical project to close tax loopholes. ${ }^{1}$ Disputing these conclusions, this Article

* Edwin S. Cohen Distinguished Professor of Law and Taxation, University of Virginia School of Law. For helpful comments, I thank Hugh Ault, Reuven Avi-Yonah, Allison Christians, Andrew Hayashi, Georg Kofler, Leandra Lederman, Shu-Yi Oei, Leopoldo Parada, Diane Ring, Wolfgang Schön, Ted Sims, Paul Stephan, Oliver Treidler, David Walker, five anonymous reviewers, and conference participants at Boston University School of Law, the EUI/OECD High-Level Policy Dialogue: Taxation Governance in Global Markets (Paris), the Indiana/ Leeds Tax Workshop, the International Tax Policy Forum (Washington), the Oxford International Tax Justice and Governance Workshop, and the University of Turin. I am particularly grateful to Tsilly Dagan and Steve Shay for reading multiple drafts. As always, the UVA Law research librarians provided excellent support.

${ }^{1}$ Reuven S. Avi-Yonah \& Haiyan Xu, Evaluating BEPS: A Reconsideration of the Benefits Principle and Proposal for UN Oversight, 6 HARV. Bus. L. REV. 185, 208 (2016) (describing BEPS as a "patch-up of existing rules and principles”); Graeme S. Cooper, Implementing BEPS, or Maybe Not-The Australian Experience One Year on, 2017 N.Z. L. REv. 145, 150 ("it is not hard for a country to commit to implement reports which skirt danger, are vague and ultimately anemic"); Mindy Herzfeld, The Case Against BEPS: Lessons for Tax Coordination, 21 FLA. TAX REV. 1, 59 (2017) ("the final BEPS reports were so watered down as to be meaningless"); Allison Christians, BEPS and the New International Tax Order, 2016 BYU L. Rev. 1603, 1604 (2016) (conceiving of BEPS chiefly as a move by 
argues that by focusing narrowly on the technical recommendations arising from BEPS, commentators have overlooked its more profound implications. In particular, BEPS reflectedand to a significant extent operationalized — major changes in the participants, agenda, institutions, norms, and legal instruments of international tax.

First, BEPS expanded the actors who participate in international tax policymaking. For most of the twentieth century, international tax policy was made by a small club of mostly rich countries under the auspices of the OECD. But BEPS opened international tax to the G20, bringing a much-needed emerging-economy perspective to international tax. Second, BEPS significantly expanded the agenda of international tax policymaking, thereby commensurately expanding the importance of the role of the OECD. Third, for most of the twentieth century, the strongest norm in international tax was that companies should not pay tax twice, but BEPS both reflected and effectuated what might be called "full taxation," a norm that income should not escape tax. ${ }^{2}$ Fourth, BEPS introduced novel forms of law, including an innovative multilateral treaty to update participating countries' bilateral tax treaties and new forms of soft law and institutional structures uniquely suited to both preserving tax sovereignty and defeating state defection. Among these instruments are what this Article calls "fiscal fail-safes," devices designed to achieve full taxation by assuring that if one state does not tax all of a company's income, another state will. Fifth, BEPS intensified old debates about the distribution among countries of the entitlement to tax income from international commerce.

The fracturing of consensus over a "century-old, mostly European gentlemen's agreement" 3 _ and in particular, a sharpening dispute between the United States and Europe over the taxation of digital giants, such as Facebook and Amazon-has prompted ongoing negotiations over the global tax split. The newly more inclusive institutions of international tax may not be fit for the task of mediating these disputes. BEPS thus leaves international tax at an inflection point. ${ }^{4}$ For a hundred years, international tax has consisted of a collection of isolated national tax regimes, connected on a piecemeal basis by bilateral tax treaties that follow a model drafted by a small set of OECD member countries. The future could bring at least three possibilities - reversion to bilateralism as the dominant form of international tax policymaking, partial rejection of the status quo bilateral tax-treaty network paired with

the OECD to secure control of international tax policy against "rival international tax policy-making institutions"); Rifat Azam, Ruling the World: Generating International Tax Norms in the Era of Globalization and BEPS, 50 SufFolK U. L. REV. 517, 523 (2017) ("I do not expect the BEPS project to substantially impact the international tax regime"). For more charitable views, see Yariv Brauner, Treaties in the Aftermath of BEPS, 41 Brook. J. INT'L L. 973, 1023, 1041 (2016) (observing that the BEPS recommendations were "the best that the OECD could politically achieve" but that "at best, the project will likely result in minimal reform of the international tax regime and its institutions"); Arthur J. Cockfield, Shaping International Tax Law and Policy in Challenging Times, 54 STAN. J. INT'L L. 223, 224, 231 (2018) (the "emphasis on multilateralism is a positive step" although BEPS "mainly contemplates modest reforms"). Others view the current environment as at least potentially transformative. See, e.g., Steven A. Dean, A Constitutional Moment in Cross-Border Taxation (forthcoming); Rasmus Corlin Christensen \& Martin Hearson, The New Politics of Global Tax Governance: Taking Stock a Decade After the Financial Crisis, 26 Rev. Int'L Pol. Econ. 1068 (2019).

${ }^{2}$ Full taxation is one of two elements of "single taxation," the other is the norm against double taxation. See discussion in Part II.C infra.

${ }^{3}$ Lee Sheppard, The Twilight of the International Consensus, 141 TAX NOTES 7 (2013).

${ }^{4}$ See also Steven Dean, Closing Remarks, 24 Fordham J. Corp. \& Fin. L. 317, 317 (2019) (describing a "constitutional moment" in international tax). 
greater unilateralism and the reemergence of double taxation, or expansion and deepening of multilateralism.

Part II provides background on the taxation of multinationals, and it explains how legal regimes and economic developments contributed to corporate tax avoidance in the twentieth century. In the twenty-first century, revenue pressures created by the 2008 financial crisis combined with public backlash against corporate tax dodging to generate the political impetus needed to embark upon the multilateral BEPS Project. Part III argues that although the most obvious outcomes of this cooperative effort-the BEPS "deliverables" — may seem modest, that modesty obscures potentially transformative developments in international tax. By expanding the ambition of international tax cooperation and increasing its revenue rewards, the BEPS Project also turned up the heat on long-simmering disputes over how to divide the tax spoils of globalization. To date, those disputes remain unresolved. Part IV takes stock of the changes wrought by BEPS from the perspectives of revenue, inclusivity, legitimacy and accountability, policy innovation, and durability. It then considers potential outcomes of the current allocation dispute.

\section{TAX Policy AND The 2008 CRISIS}

Throughout the twentieth century, states faced a collective action problem, stemming from pressures to compete for mobile business and investment, that prevented them from cooperating to combat corporate tax avoidance. This reluctance to cooperate changed in 2008 when public investigations, a series of leaks, and the global financial crisis provided the political impetus for meaningful multilateral reform, which resulted in the BEPS Project. ${ }^{5}$

\section{A. The Basics of the International Tax System}

The current international tax system-which consists of domestic tax regimes and an extensive network of bilateral tax treaties to connect them-relies on the concepts of source and residence. Corporate tax residence is clearly, albeit arbitrarily, defined as a company's place of incorporation or its place of management and control. ${ }^{6}$ Under tax treaties and international custom, a state may tax a nonresident corporation only on income "sourced" in its territory. ${ }^{7}$ Unlike source states, the company's state of residence may tax all of the company's worldwide income. ${ }^{8}$ Treaties require residence states to relieve any resulting double taxation either by exempting income taxed at source or by crediting the source tax against residence tax

\footnotetext{
${ }^{5}$ For first-hand accounts, see Pascal Saint-Amans, 20th Annual David R. Tillinghast Lecture on International Taxation (NYU School of Law), YouTube (Oct. 19, 2015), at https://www.youtube.com/watch?v=K8V_6j1gx-k (speech, by the OECD's tax head, reflecting on developments); Manal Corwin, 19th Annual David R. Tillinghast Lecture on International Taxation (NYU School of Law), YouTuBE (Oct. 7, 2014), at https://www.youtube.com/

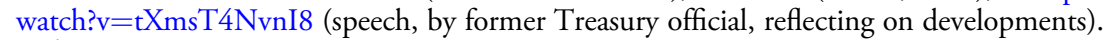

${ }^{6}$ Model Tax Convention on Income and on Capital, Art. 4 (OECD Comm. on Fiscal Affairs 2017) [hereinafter OECD MODEL] (defining residence by reference to domestic law). See generally Omri Marian, Jurisdiction to Tax Corporations, 54 B.C. L. Rev. 1613 (2013) (discussing domestic definitions of corporate tax residence).

${ }^{7}$ Mitchell A. Kane, A Defense of Source, 32 Yale J. Reg. 311, 326-31 (2015) (source rules serve a distributive function and reflect geographic location of income); Stephen E. Shay, J. Clifton Fleming, Jr. \& Robert J. Peroni, "What's Source Got to Do with It?" Source Rules and U.S. International Taxation, 56 TAX L. REV. 81 (2002) (source reflects legal jurisdiction to tax).

${ }^{8}$ OECD MODEL, supra note 6, Art. 7.
} 
due. ${ }^{9}$ In the absence of tax treaties, residence states typically relieve double tax unilaterally. In addition to assuring such double-tax relief, tax treaties shift tax revenue from source to residence by constraining source tax entitlements; tax treaties also coordinate other tax administrative functions, including information sharing. ${ }^{10}$

Although the OECD has only thirty-seven members, most countries follow the OECD Model tax treaty, ${ }^{11}$ which traces its origins to the 1920 s. ${ }^{12}$ Under this model, states agree to two limits on source taxation of business profits. First, a state may tax nonresident companies only if the company has a "permanent establishment" there, meaning a physical presence or dependent agent. ${ }^{13}$ Second, if a nonresident has a permanent establishment in the source state, then that state may tax only the income "attributable" to that permanent establishment. ${ }^{14}$ To determine the attributable income, the source state imagines that the permanent establishment is its own entity, independent of its head office, and then imputes an "arm's-length" return to the permanent establishment. Widely followed throughout the world, the OECD Transfer Pricing Guidelines and other OECD guidance explicate this attribution process both for permanent establishments and separate legal entities in a multilateral corporate group. ${ }^{15}$ Before BEPS, the OECD Model tax treaty, Commentary on that model, and the Transfer Pricing Guidelines represented the most important modes of multilateral standard-setting in corporate taxation. ${ }^{16}$ Despite being soft law, adherence to these standards is widespread among both OECD and non-OECD countries. For example, the OECD Model serves as the basis for both the U.S. and UN model tax treaties. ${ }^{17}$

\section{B. Corporate Tax Avoidance}

For most of the twentieth century, policymakers saw corporate tax avoidance as unproblematic, or regarded the costs of curbing it as too high. This section points to legal and economic factors that intensified and continue to intensify corporate tax avoidance; it explains that unilateral efforts to curb corporate avoidance in the last century were largely unsuccessful, and it identifies barriers to multilateral cooperation to curb corporate tax avoidance.

9 See, e.g., id. Art. 23.

${ }^{10}$ Tsilly Dagan, The Tax Treaties Myth, 32 N.Y.U. J. InT'L L. \& Pol. 939 (2000).

${ }^{11}$ See generally Pasquale Pistone, General Report, in The ImPact of The OECD and UN Model Conventions on Bilateral Tax Treaties (2012) (Michael Lang, Pasquale Pistone, Josef Schuch \& Claus Staringer eds., 2012).

${ }^{12}$ For historical background, see Michael J. Graetz \& Michael M. O'Hear, The “Original Intent" of U.S. International Taxation, 46 Duke L.J. 1021 (1997); Sunita Jogarajan, Double Taxation and the LeaGue of NATIONS (2018).

${ }^{13}$ OECD Model, supra note 6, Art. 5.

${ }^{14}$ Id. Art. 7.

${ }^{15}$ See, e.g., OECD, Report on the Attribution of Profits to Permanent Establishments (2010); OECD, Transfer Pricing Guidelines for Multinational Enterprises and Tax Administrations (2017) [hereinafter Transfer Pricing Guidelines].

${ }^{16}$ Although the OECD standard-setting process is multilateral, the legal instruments it generates-tax treaties — are bilateral. Most countries use the OECD Commentary and the Transfer Pricing Guidelines to help interpret their tax treaties. See Pistone, supra note 11. States also have developed multilateral agreements at the OECD in the areas of tax information exchange and administrative assistance. See Azam, supra note 1, at 543-46.

${ }^{17}$ For more on the influence of the OECD Model and guidance, see Pistone, supra note 11. 


\section{Intensifiers}

Several factors intensify corporate tax avoidance, including legal, economic, and technological factors; the growing obsolescence of tax treaties; and differences in tax rules across states. These same factors also intensify competition among states both for paper profits, which generate tax revenue, and for real factors of production, which generate wealth and jobs for national residents.

Changes in law, economy, and technology. Liberalization of trade, commercial, and financial flows increase pressures on states to make their tax regimes appeal to highly mobile business and investment. ${ }^{18}$ As this section explains, the rise of the internet and other communications technologies enables new forms of business, and the dominance of the world economy by highly integrated, intellectual-property-intensive global firms has increased taxpayers' access to tax planning techniques that depend on exploiting differences in national tax laws. ${ }^{19}$

Obsolescence of technical provisions. The obsolescence of technical provisions in tax treaties also contributes to corporate tax avoidance. The requirement for a physical presence or a dependent agent in the source state to satisfy legal nexus for tax purposes was well-suited to a bricks-and-mortar economy. But the replacement of offices, factories, and warehouses with immaterial websites and cheap third-party contracts for manufacturing, warehousing, and delivery has enabled multinationals to avoid tax nexus in source states. Companies' lack of physical presence in a jurisdiction does not necessarily mean lack of engagement in the local economy, or lack of associated profits, but increasingly, states cannot reach those profits because companies do not satisfy a tax nexus requirement designed for an earlier era.

National fragmentation. Even when multinationals cannot avoid having a taxable presence in a state, they bring the considerable creativity (and chutzpah) of the tax bar to the task of minimizing their tax bills via brazen and inventive tax planning techniques that exploit differences in national legal regimes. Fragmentation of tax law into national systems facilitates both tax competition among states and aggressive tax planning. Following common practice, this Article uses "profit shifting" to refer to any strategy for avoiding tax by manipulating where a company is deemed for tax purposes to earn income. In a world where states set their tax rates independently from each other, a company that can choose where to declare its income also can choose its tax rate.

Multinational groups shift profits by, for example, moving valuable intellectual property to low-tax jurisdictions and then charging artificially high licensing fees to related companies in high-tax jurisdictions. The related group member in the high-tax state gets a large deduction, and, by design, the recipient of the fee is taxable in a low-tax state. The group's overall profit

\footnotetext{
18 OeCD, Harmful Tax Competition: An Emerging Global Issue (1998) [hereinafter 1998 OECD REPORT].

${ }^{19}$ Some of international tax's sharpest legal critics have chronicled these strategies. See, e.g., Edward D. Kleinbard, Stateless Income, 11 Fla. TAX ReV. 699 (2011), Bret Wells \& Cym Lowell, Tax Base Erosion and Homeless Income: Collection at Source Is the Linchpin, 65 Tax L. Rev. 535 (2012); J. Clifton Fleming, Jr., Robert J. Peroni \& Stephen E. Shay., Getting Serious About Cross-Border Earnings Stripping: Establishing an Analytical Framework, 93 N.C. L. Rev. 673 (2015). Prominent economists have contributed crucial insights. See, e.g., Rosanne Altshuler \& Harry Grubert, The Three Parties in the Race to the Bottom: Host Governments, Home Governments and Multinational Companies, 7 Fla. TAX Rev. 137 (2005); Kimberly A. Clausing, Multinational Firm Tax Avoidance and Tax Policy, 62 NAT'L TAx J.703 (2009); Jane G. Gravelle, Tax Havens: International Tax Avoidance and Evasion, CONG. RES. SERV. (Jan. 15, 2015), available at http://fas.org/sgp/crs/misc/ R40623.pdf.
} 
remains the same, but it saves tax due to the rate differential. This kind of payment between related companies is called a "transfer price."

Other inventive tax-avoidance techniques take advantage of differences in legal regimes or definitions between different states. For example, Apple, the U.S.-headquartered technology giant, famously exploited a difference between the U.S. and Irish definitions of tax residence. ${ }^{20}$ Ireland considered a company to be a tax resident only if it was managed and controlled in Ireland. In contrast, the United States determined residence by place of incorporation. By incorporating subsidiaries in Ireland, but managing and controlling them from the United States, Apple created companies that resided nowhere for tax purposes. ${ }^{21}$ By shifting income to these stateless subsidiaries, Apple moved a large portion of its global profits to nowhere, thereby escaping tax. ${ }^{22}$ Other companies were less audacious than Apple, but they were able to achieve the same functional result by using tax havens with no or very low corporate taxes. ${ }^{23}$

\section{Unilateral Measures}

Although governments knew about these tax-avoidance techniques, before BEPS their unilateral responses did not combat them effectively. Competitive pressures and the influence of private business help to explain this lack of effectiveness. On the competitive front, source states that allowed a lot of profit shifting presumably calculated that they preferred inbound investment and business activity to the additional revenue that strict tax enforcement would have generated. An influx of jobs and investment might warrant ignoring excessive outbound deductible payments made to related parties. Moreover, powerful private interests opposed measures to counter tax avoidance.

In principle, the growing inability (or reluctance) of source states to tax multinationals should have enlarged residence states' tax entitlements. But likewise catering to business interests and driven by competitive pressures, residence states also often did not tax. ${ }^{24}$ As states competed with each other, headline corporate tax rates fell. ${ }^{25}$ Although they typically could not afford to offer the extremely low across-the-board rates found in tax havens, otherwise high- or middle-tax states lowered their tax rates and introduced preferential tax regimes to attract mobile activities. ${ }^{26}$

${ }^{20}$ Ruth Mason, Special Report on State Aid - Part 3: Apple, 154 Tax Notes 735, 736 (2017).

${ }^{21}$ S. Subcomm. on Investigations, Hearings on Offshore Profit Shifting and the U.S. Tax Code- Part 2 (Apple Inc.), at 45 (Comm. Print 2013) (testimony of Apple chief executive officer Tim Cook) [hereinafter Senate Apple Hearings].

${ }^{22}$ See id. at 20.

${ }^{23}$ See generally Kleinbard, supra note 19.

${ }^{24}$ Domestic laws, such as exemption provisions, may prevent tax at residence automatically, regardless of whether income was taxed at source. That residence states did not fix these gaps can be explained several ways: policymakers may have assumed — without verifying - that income would be taxed abroad; they may have exempted foreign income to compete with other states for corporate residents, and they may have believed that nontaxation provided resident companies a competitive advantage abroad. To avoid triggering residual residencestate taxation, companies also employed creative ways to appear as if they had no foreign income subject to current taxation by the residence state.

${ }^{25}$ OeCD, Addressing Base Erosion and Profit Shifting 15-16 (2013) [hereinafter Addressing BePS] ("statutory corporate income tax rates in OECD member countries dropped on average 7.2 percentage points between 2000 and 2011, from $32.6 \%$ to $25.4 \% ")$.

${ }^{26} 1998$ OECD REPORT, supra note 18, at 19-37 (detailing such regimes). 
As the economy globalized, states' losses from failure to curb tax avoidance mounted. Mere paper profit shifting generated revenue losses, but factors of production also moved as companies responded to tax incentives. ${ }^{27}$ Unilateral efforts to counter tax avoidance were not very successful. For example, in the late 1960s, the United States passed so-called controlled-foreign-corporation (CFC) rules. ${ }^{28}$ Under the CFC rules, shifting profits to or among foreign subsidiaries triggered tax for the U.S. parent on the shifted income, at high pre-2017 U.S. corporate tax rates. ${ }^{29}$ But in the late 1990s, the Treasury Department gutted the CFC rules when it implemented the "check-the-box" regulations. Weary of fighting with taxpayers about how entities should be characterized for tax purposes, Treasury decided that, within certain limits, U.S. taxpayers could elect whether their business entities would be taxed separately or as pass-throughs. ${ }^{30}$ The only thing that companies-including foreign companies ${ }^{31}$ - had to do was file a form and check the box for their desired treatment. ${ }^{32} \mathrm{~A}$ taxplanner's dream, but a tax official's nightmare, check-the-box provided an easy way to manufacture hybrid entities that were taxed as corporations in one jurisdiction but passthroughs or branches in another. Without check-the-box, shifting income among foreign affiliates would potentially generate tax to the U.S. parent under the CFC rules. By checking the box to regard a foreign entity as a branch of its parent, however, the U.S. parent could make profit-shifting payments disappear-for U.S., but not foreign-tax purposes. ${ }^{33}$ Check-the-box defanged the CFC rules, enabling U.S.-parented companies to shift profits between foreign affiliates with impunity.

In part to counter profit-shifting, the United States also developed-and convinced the rest of the world to accept - the arm's-length standard. ${ }^{34}$ Memorialized in hundreds of pages of OECD Transfer Pricing Guidelines, as well as various national rules and regulations, the arm's-length standard limits profit shifting by requiring each member of a corporate group to report a market, or arm's-length, transfer price on transactions. ${ }^{35}$ Determining the arm'slength price requires estimating what the price would have been if the members of the group were

27 AdDRESSING BEPS, supra note 25, at 15-23 (reviewing empirical studies).

${ }^{28}$ IRC $\$ \$ 951-65$ (deeming certain kinds of passive or shifted foreign profits of foreign subsidiaries of U.S. shareholders to be earned directly by their U.S. shareholders).

${ }^{29}$ Before 2017, the U.S. corporate tax rate was 35\%, one of the highest in the world. Since 2017, it has been $21 \%$, a rate more aligned with that of major U.S. trading partners.

${ }^{30}$ Notice 95-14, 1995-1 CB 297.

31 Treas. Reg. $\$ 301.7701-1$ to -2 .

32 Treas. Reg. $\$ 301.7701-1$ to -3 (providing elections); IRS Form 8832 (entity classification form).

33 As a simple example, the receipt by a second-tier foreign subsidiary in a low-tax jurisdiction (HavenCo) of interest from a first-tier operating company in a high-tax jurisdiction (OpCo) could be taxable to OpCo's U.S. parent (USCo) under U.S. CFC rules. Checking the box to disregard HavenCo as a separate entity from its parent (OpCo), however, would make the interest disappear from the perspective of the U.S. tax system; the United States would ignore both the payment and receipt of the interest. But OpCo's residence state would still see the interest payment, and would still allow OpCo to deduct it. The payment of deductible interest therefore shifts profits from high-taxed OpCo to low-taxed HavenCo, without triggering the U.S. CFC rules.

${ }^{34}$ IRC $\$ 482$. For the history of the standard since 1935 and the role of the United States in disseminating it, see Reuven S. Avi-Yonah, The Rise and Fall of Arm's-Length: A Study in the Evolution of U.S. International Taxation, 15 VA. TAX ReV. 89 (1995); Stanley I. Langbein \& Max R. Fuss, The OECD/G20-BEPS-Project and the Value Creation Paradigm: Economic Reality Disemboguing into the Interpretation of the "Arm's Length" Standard, 51 INT'L L. 259 (2018).

35 See Transfer Pricing Guidelines, supra note 15, at 33 (elucidating the OECD standard). See also Treas. Reg. $\$ \$ 482-1$ to $482-9$. 
unrelated. ${ }^{36}$ Analysis of comparable transactions among unrelated parties helps taxpayers and tax administrators determine this figure, ${ }^{37}$ but the arm's-length standard has faced significant and warranted criticism because arm's-length comparables are often unavailable and other methods for estimating appropriate transfer prices are unreliable or subjective. ${ }^{38}$ Fuzzy standards and methods provide taxpayers significant discretion over where to report their income. Even when governments contest transfer prices, they have found it difficult to persuade courts that their estimations of arm's-length prices ought to prevail over taxpayers' estimations. ${ }^{39}$ Indeed, the arm's-length standard is said to produce a "range" of correct answers, such that the choice of a point within that range is arbitrary. ${ }^{40}$ Courts are understandably reluctant to impose unfavorable results on taxpayers based on subjective, unclear, or arbitrary standards and regulations. ${ }^{41}$ The subjectivity of the standard and taxpayers' successes in fending off adjustments by governments have emboldened taxpayers to aggressively manipulate transfer pricing in order to shift income. ${ }^{42}$

Similar to the United States, other countries passed limited anti-abuse measures meant to stem the leakage from their own tax systems, ${ }^{43}$ and OECD countries worked together to strengthen and revise the OECD Transfer Pricing Guidelines. ${ }^{44}$ But on the whole, and motivated by competitive pressures and pressure from corporate special interests, most states took an indulgent attitude toward corporate tax avoidance. The history of check-the-box serves as an instructive example. One consequence of check-the-box was that it enabled U.S. companies to pay less foreign tax, without suffering any U.S. tax penalty. U.S. lawmakers became convinced that such foreign tax savings could help U.S. companies compete against companies headquartered elsewhere. In addition, lower foreign taxes for U.S. companies itself lowered the U.S. obligation to credit foreign taxes. This gave the United States both competitive and revenue reasons to turn a blind eye to U.S. multinationals' foreign profit shifting. Other countries never retaliated for check-the-box, and efforts by U.S. tax officials to claw back the benefit faced major opposition from multinationals. ${ }^{45}$

\section{Barriers to Cooperation}

Tax competition and corporate tax avoidance represented collective-action problems that no one state could tackle unilaterally without driving out valuable productive factors, such as

36 Transfer Pricing Guidelines, supra note 15, at 101-17.

${ }^{37}$ Id.

${ }^{38}$ There is no shortage of criticism of the arm's-length standard. See, e.g., Avi-Yonah, supra note 34; Wells \& Lowell, supra note 19.

39 See generally IRS Notice 88-123, 1988-2 CB 458, at S-6 (noting the government's judicial losses).

40 Transfer Pricing Guidelines, supra note 15, at 23 (defining "arm's-length range").

${ }^{41}$ See Reuven S. Avi-Yonah, The Structure of International Taxation: A Proposal for Simplification, 74 Tex. L. REv. 1301, 1344-46 (1996) (providing examples).

42 The flexibility of the standard also leads to double taxation when two different jurisdictions disagree on the treatment of a single, cross-border transaction or interaction, and each seeks to tax in full, or one jurisdiction seeks an upward price adjustment, but the other refuses to make a corresponding downward adjustment.

${ }^{43}$ Sebastian Dueñas, CFC Rules Around the World, TAX Found. FISC. FACT (June 2019) (giving history).

${ }^{44}$ Langbein \& Fuss, supra note 34.

${ }^{45}$ Offshore Profit Shifting and the U.S. Tax Code - Part 2 (Apple Inc.), 113th Cong. 2 (May 21, 2013) (memorandum to the members of the Permanent Subcommittee on Investigations from Senators Levin and McCain), at 3 (noting that when Treasury tried to close the check-the-box loophole, "the proposal was met with such opposition from Congress and industry groups that it was never adopted"). 
jobs and capital. Yet numerous barriers prevented states from working together cooperatively; these barriers included heterogeneity of state interests, monitoring problems, reluctance to cede national tax sovereignty, lack of clear ideas about how to close even notorious tax gaps, inability to grasp the scope of the problem, interest-group capture, and views that tax competition was normatively desirable.

State heterogeneity and monitoring costs. Although states made some efforts to curb tax competition and corporate tax avoidance, the unequal distribution of the potential benefits from cooperation (which would mostly redound to high-tax states) constituted a major impediment to collective action. Small states with few natural resources used taxes to compete for inbound investment that they could not otherwise win; some even become tax havens. ${ }^{46}$ Such countries could not be persuaded to cooperate by the promise that cooperation would yield more tax revenue. Instead, overcoming their incentives to defect required either strict monitoring and penalties or side payments. Side payments were politically unpalatable, as were penalties, and monitoring posed special challenges in taxation because competition takes place on a variety of fields, some nontransparent. For example, while headline rates are relatively transparent, states can also attract taxpayers through lenient tax enforcement, favorable legal interpretations, and even secret tax deals. ${ }^{47}$

Tax sovereignty. Harmonizing tax laws across countries would eliminate tax competition, but concerns about preserving national tax sovereignty scuttled multilateral efforts to combat tax avoidance through harmonization. ${ }^{48}$ Tax sovereignty encompasses several concerns, some normatively desirable, some not.

First, ceding authority to a supranational body to determine important tax policies would reduce national legislators' ability to respond to voter preferences, which differ across states. The existence of such differences in preferences represents the most powerful normative argument in favor of tax autonomy and, by extension, tax competition. Second, and less normatively desirable, national lawmakers may be rationally reluctant to shift decision-making power to supranational institutions because doing so reduces their own opportunities to deliver particular tax-policy outcomes to interest groups. While accommodating rent-seeking at the national level may not be normatively desirable, it is not clear than rent-seeking at the supranational level would be any better, ${ }^{49}$ and in any case, the desire to retain control over rents at the national level impedes international cooperation.

${ }^{46}$ See Michael Keen \& Kai A. Konrad, The Theory of International Tax Competition and Coordination, in 5 Handbook of Public Economics 257, 310 (Alan J. Auerbach, Raj Chetty, Martin Feldstein \& Emmanuel Saez eds., 2013) (acknowledging that defining tax havens involves "hazy" line-drawing, but that "three features seem to capture the essence: low taxation that is not a reflection of high revenue, relative to needs, from other sources; the attraction of profit-shifting and other tax arbitrage activities more than real activity; and imperfect sharing of information"); Adam H. Rosenzweig, Why Are There Tax Havens?, 52 WM. \& Mary L. Rev. 923 (2010).

${ }^{47}$ Omri Marian, The State Administration of International Tax Avoidance, 7 HARV. Bus. L. Rev. 1, 30 (2017) (concluding that Luxembourg created bespoke tax shelters for foreign multinationals). Some of these deals may have violated EU law. See Ruth Mason, Identifying Illegal Subsidies, 69 Amer. U. L. Rev. 479 (2019) (critically evaluating the Commission's recent state-aid investigations involving transfer-pricing rulings).

${ }^{48}$ See e.g., Commission Communication, Towards a More Efficient and Democratic Decision Making in EU Tax Policy, COM(2019) 8 of Jan. 15, 2009, at 1. See id. (observing that "taxation has been closely linked to national sovereignty, due to its role in national revenues, budgets and policy choices. Member States have defended this sovereignty").

${ }^{49}$ Indeed, there are reasons to think it would be worse, including that it would shift the target of the rent-seeking behavior from national politicians, who are subject to electoral discipline, to unelected tax administrators who represent their countries at the OECD. 
Concerns regarding national tax sovereignty apply regardless of state size. Tax autonomy enables small states to defect from cooperative solutions that are unlikely to benefit them. ${ }^{50}$ Tax autonomy likewise enables large, and especially rich, countries to pursue a divide-andconquer strategy with respect to smaller and poorer states. This can be seen in tax treaties, which shift tax entitlements from poor to rich states as compared to the no-treaty situation. ${ }^{51}$ Yet rich states' retention of tax sovereignty — which enables them to exploit their power asymmetry in other tax areas-imposes a cost; it weakens their ability to respond cooperatively to tax competition.

Legality of tax gaps. The perceived legality of corporate-tax-avoidance strategies also served as a barrier to collective action. Unlike tax evasion, which typically includes fraud or other overt law-breaking, tax avoidance techniques do not violate the law of any state. Instead, they often merely exploit differences in different states' laws. ${ }^{52}$ Apple's stateless companies are a perfect example-Ireland defined tax residence one way, the United States another. When income fell through the gaps between the two states' systems, neither state felt obliged to catch it. ${ }^{53}$ The effects of check-the-box were similar-why should another country care how the United States characterized an entity for tax purposes? As long as neither state regarded itself as losing revenue owed to it, why should either be concerned about the taxpayer's activities or income elsewhere? ${ }^{54}$ As David Rosenbloom put it, "The beauty of international tax arbitrage, when practiced most skillfully, is that none of the objections to aggressive or abusive tax planning should apply anywhere because, from the vantage point of any single country, there is neither aggressiveness nor abuse." 55 There was also a question of how countries could close loopholes without harmonizing their tax systems, which they did not want to do. ${ }^{56}$ Who but the Irish could tell Ireland how to define corporate tax residence? Every state possessed autonomy to create the tax system its voters found most suitable, and that autonomy led inevitably to gaps and overlaps in taxation. The very legality of aggressive tax planning thus made it difficult not only to conceive of solutions, but even to recognize that there was a problem that needed to be solved.

Hidden scope. Yet another reason for complacence in combatting tax avoidance was that officials did not understand the full scale of the problem. The scope of corporate tax avoidance was obscured not only by its legality, but also its elusiveness. Economists' estimates of profit

${ }^{50}$ See Ronen Palan, Tax Havens and the Commercialization of State Sovereignty, 56 INT'L Org. 151 (2002). Even wealthy states commercialize aspects of their sovereignty, including by offering tax-free zones and other ringfenced regimes. See, e.g., OECD, Progress in Identifying and Eliminating Harmful Tax Practices (2001) 1214 (listing "preferential" tax regimes in OECD states).

${ }^{51}$ For resources discussing the poor-to-rich revenue shift caused by tax treaties, see notes 269 to 270 infra. Rich states typically are net residence states when they negotiate treaties with poor states. Given how well understood these effects are, there is no reason to think that they are not deliberate.

${ }^{52}$ Cf. H. David Rosenbloom, The David R. Tillinghast Lecture International Tax Arbitrage and the "International Tax System," 53 Tax L. ReV 137 (2000).

${ }^{53}$ Much has been written on corporate tax arbitrage. See, e.g. id.; Diane M. Ring, One Nation Among Many: Policy Implications of Cross-Border Tax Arbitrage, 44 B.C. L. Rev. 79, 85 (2002); Mitchell A. Kane, Strategy and Cooperation in National Responses to International Tax Arbitrage, 53 EmORY L.J. 89 (2004); Adam H. Rosenzweig, Harnessing the Costs of International Tax Arbitrage, 26 VA. TAX REv. 555 (2007).

${ }^{54}$ See Rosenbloom, supra note 52, at 144 (arguing that nothing "should or can be done about [international tax arbitrage]").

55 Id. at 143.

${ }^{56}$ See, e.g., Brauner, supra note 1, at 980 ("the international tax regime has also been dominated by the perceived binary choice between competition and harmonization”). 
shifting varied widely, as did estimates of revenue losses, reflecting both gaps in data and problems with cross-country comparability data that did exist. ${ }^{57}$ Because companies report taxable income at the national, not global, level, a particular state's tax authorities could not see the full income picture for any multinational. ${ }^{58}$ So while economists observed indirect evidence of income shifting-for example that the foreign direct investment into tax havens like Bermuda and the Cayman Islands was orders of magnitude higher than would be expected given the features of those countries' economies ${ }^{59}$ — no one knew how much income was declared in those havens, how much income was declared nowhere, or how much income, if any, a particular state lost from corporate tax avoidance. ${ }^{60}$

Regulatory capture. Powerful, well-organized corporate special interests also resisted effective responses to aggressive corporate tax planning, whether unilateral or cooperative, and there is ample evidence that companies play jurisdictions against each other to get the best tax deal. ${ }^{61}$

Normative reluctance. The traditional argument in favor of cooperation to curb tax competition is that, without it, states will be unable to meet their domestic social welfare commitments. ${ }^{62}$ But empiricists had trouble showing such impacts, and proponents of tax competition pointed to its normative benefits, including that it acts as a salutary check on big government, an efficient means to satisfy voter preferences that differ across jurisdictions, and an efficient response to the mobility of certain investments. ${ }^{63}$

Conclusion. Due to these barriers, a project at the OECD in the late 1990 s to curb tax competition made important, but only limited, progress. ${ }^{64}$ Likewise, a contemporaneous project within the EU to use state-aid enforcement to curb tax competition petered out. ${ }^{65}$ Moreover, when countries undertook cooperative efforts to combat tax competition, because they were

${ }^{57}$ ADDRESSING BEPS, supra note 25, at 15-25, 61-73 (2013) (reviewing recent empirical work).

${ }^{58}$ Edward D. Kleinbard, Through a Latte, Darkly: Starbucks's Stateless Income Planning, 139 TAX NoTES 1515 (2013) (highlighting information gaps between taxpayers and tax administrations).

59 ADDRESSING BEPS supra note 25 at 17 (there is "abundant circumstantial evidence that BEPS behaviors are widespread"). As one example, the OECD noted that in 2010, Barbados, Bermuda, and the British Virgin Islands received more foreign direct investment than did Germany, and the British Virgin Islands was the world's largest investor in China, well ahead of the United States. Id.

${ }^{60}$ Economists have closely studied profit shifting, but they disagree over its extent. See id. at 61-71 (literature review).

${ }^{61}$ Cf. Peter D. Enrich, Saving the States from Themselves: Commerce Clause Constraints on State Tax Incentives for Business, 110 Harv. L. REV. 377 (1996) (examining subnational tax in the United States).

${ }^{62}$ Reuven S. Avi-Yonah, Globalization, Tax Competition, and the Fiscal Crisis of the Welfare State, 113 HarV. L. Rev. 1573 (2000).

${ }^{63}$ The literature on tax competition is voluminous. For literature reviews, see, for example, Keen \& Konrad, supra note 46; Tsilly Dagan, International Tax Policy: Between Competition and Cooperation 120-41 (2018); for contemporary arguments in favor of tax competition, see, for example, Julie Roin, Competition and Evasion: Another Perspective on International Tax Competition, 89 GEo. L.J. 543 (2000); David C. Elkins, The Merits of Tax Competition in A Globalized Economy, 91 IND. L.J. 905 (2016).

${ }^{64}$ See Martin Hearson, The OECD and the Lost Battle to Impose Sanctions on Tax Havens, LSE Bus. REv. (2016). Among the accomplishments of the OECD Harmful Tax Practices Project were an increase in transparency and peer review that continue to this day, an approach to identifying harmful tax competition that persists and was used in BEPS, and the establishment of the Global Forum on Tax Transparency. See Hugh J. Ault, Reflections on the Role of the OECD in Developing International Tax Norms, 34 BRook. J. INT'L L. 757, 763-72 (2009).

65 See Lilian V. Faulhaber, The Trouble with Tax Competition: From Practice to Theory, 71 TAx L. REV. 311, 327-32 (2018) (describing OECD and EU Code of Conduct initiatives); Ruth Mason, Special Report on State Aid -Part 1: State Aid FAQ, 154 TAX Notes 451 (2017) (explaining early use and quiet abandonment of state-aid investigations to enforce EU conceptions of harmful tax competition). 
guided by their own interests in securing inbound investment and advantages for their companies, they inevitably disagreed about what forms of competition ought to be prohibited. ${ }^{66}$ Thus, while states cooperated to eliminate tax overlaps that led to double taxation, they left tax gaps unresolved. Several states even made a tidy living by deliberately creating tax gaps for multinationals to exploit. ${ }^{67}$ And when other states inadvertently created loopholes, such as check-the-box, they found that interest groups sprang into action to prevent repeal. ${ }^{68}$

\section{Crisis and the Road to Cooperation}

Given these barriers to cooperation to curb corporate tax avoidance, the goals of transnational tax governance in the twentieth century were modest: to continually and incrementally improve common standards, such as the OECD Model, Commentary, and the Transfer Pricing Guidelines. International tax was largely ignored by foreign ministers and even, to a surprising extent, by finance ministers. Tax bureaucrats tinkered with technical challenges, but they did not undertake fundamental reform of the taxation of multinationals.

The tranquility of the tax bureaucrats and the complacency of political leaders ended abruptly with the 2008 financial crisis, which triggered job losses, budget and monetary crises, and a new intolerance of corporate tax dodging. ${ }^{69}$ Leaks and public investigations increased scrutiny of corporate taxation and galvanized decisive action by national leaders. Voters who had mostly ignored cross-border tax issues suddenly started paying attention. This section explains that these new factors overcame previous barriers to cooperation, paving the way for the BEPS Project, a major multilateral effort to curb corporate tax avoidance. Changes in preexisting institutions_-including the G20 and the EU-also facilitated multilateral cooperation.

Investigations by the United States and United Kingdom of corporate tax avoidance galvanized popular attention, especially among European voters, who had experienced years of austerity budgets following the 2008 crisis. In September 2012, the Senate's Permanent Subcommittee on Investigations held hearings on corporate tax avoidance that included testimony from executives from Microsoft and Hewlett Packard. ${ }^{70}$ Less than two months later, the Committee of Public Accounts of the British House of Commons conducted similar public hearings, calling executives from Amazon, Google, and Starbucks to explain why their

\footnotetext{
${ }^{66}$ See Faulhaber, supra note 65 (arguing that countries support definitions of tax competition that will help them win inbound investment). For game-theory accounts of tax cooperation, especially in tax treaties, see, for example, Tsilly Dagan, The Tax Treaties Myth, 32 N.Y.U. J. Int'L L. \& Pol. 939 (2000); Thomas Rixen, The Political Economy of International Tax Governance (2008); Adam H. Rosenzweig, Thinking Outside the (Tax) Treaty, 2012 Wis. L. Rev. 717, 728-47 (2012).

${ }^{67}$ Marian, supra note 47.

${ }^{68}$ Rosenzweig, supra note 53, at 618-20 (recounting heated controversy over attempts to repeal check-the-box).

${ }^{69}$ At the same time that corporate tax dodging drew negative attention during this period, tax authorities in the United States adopted extraordinary (and some say illegal) interpretations of existing law to cut taxes for financial institutions. See Albert H. Choi, Quinn Curtis \& Andrew T. Hayashi, Crisis-Driven Tax Law: The Case of Section 382, 23 Fla. Tax. Rev. 1 (2019).

${ }^{70}$ Offshore Profit Shifting and the U.S. Tax Code - Part 1 (Microsoft \& Hewlett Packard): Hearing Before the Permanent Subcomm. on Investigations of the S. Comm. on Homeland Sec. \& Governmental Affairs, 112th Cong. 2 (2012).
} 
companies reported such small profits in the United Kingdom, despite their apparent success there. $^{71}$

The explosive parliamentary hearings included testimony from a Starbucks executive that the company had received a "low-tax ruling" from the Netherlands, but that the Dutch tax authority had "asked [Starbucks] not to share [it] publicly." 72 The executive also insisted that, despite a dramatic expansion in the number of Starbucks stores in the United Kingdom, the company had been unprofitable in the United Kingdom for fourteen out of fifteen years of operation. ${ }^{73}$ The hearings made headline news around the world and led to boycotts of Starbucks by British consumers upset with the company's payment of "single-shot taxes on Venti-size sales."74

A second set of Senate hearings revealed Apple's stateless foreign subsidiaries; these subsidiaries filed full tax returns nowhere on Earth. ${ }^{75}$ At the same hearings, an Apple executive also testified that Apple had negotiated a special tax rate with Ireland, although the company later retracted this claim. ${ }^{76}$ Newspapers carried front-page stories on the tax-avoidance efforts of Apple and other prominent companies. ${ }^{77}$ "Double Irish with a Dutch sandwich" entered the vernacular as readers pored over complex diagrams published in major newspapers around the world. ${ }^{78}$

These revelations inflamed public sentiment against corporate tax dodging, as did disclosure by a $\mathrm{PwC}$ whistleblower of a trove of secret tax administrative rulings granted by the Luxembourg tax authority to clients of PwC. ${ }^{79}$ Although many of the leaked tax rulings were ordinary administrative guidance that merely confirmed application of Luxembourg law to a particular taxpayer's facts, ${ }^{80}$ others appeared to grant taxpayers secret sweetheart tax deals. ${ }^{81}$ In the public eye, this material, known as LuxLeaks, seemed to confirm suspicions that companies were not paying their fair share of taxes and, crucially, that certain

${ }^{71}$ House of Commons, Comm. of Public Accounts, HM Revenue \& Customs: Annual Report and Accounts 2011-12 (19th Rep. Sess. 2012-13). An Amazon executive fared no better in his attempt to defend Amazon’s $£ 1$ million tax bill on $£ 4$ billion in sales to the country in the prior year. Id.

${ }^{72} I d$. at 26 (testimony of Troy Alstead, Starbucks' chief financial officer).

${ }^{73} \mathrm{Id}$.

${ }^{74}$ Anthony Faiola, For Starbucks in Britain, a Skinny Tax Bill?, WASH. POST (Dec. 6, 2012) (describing "rising British wrath" in the "highly public boycott" of Starbucks motivated by revelation that since 1998, Starbucks had paid "only $\$ 13.76$ million in British corporate taxes on nearly $\$ 5$ billion in British sales").

75 Senate Apple Hearings, supra note 21, at 6.

${ }^{76}$ Id. (testimony of Phillip Bullock, Tax Operations Head of Apple, Inc.). But see id. at 20 (testimony of Tim Cook, chief executive officer of Apple) (denying that Apple negotiated taxes with Ireland). See also Apple CEO Tim Cook Grilled on Irish Tax Scandal, Assoc. PRESS (May 21, 2013) (describing the Irish Prime Minster as denying that Ireland negotiated taxes with Apple).

77 See, e.g., Faiola, supra note 74.

78 See, e.g., Charles Duhigg \& David Kocieniewske, How Apple Sidesteps Billions in Taxes, N.Y. TimES, at A1 (Apr. 28, 2012). The strategy derived its name because the structure typically employed, beneath the U.S. parent, second- and fourth-tier Irish subsidiaries with a third-tier Dutch subsidiary between them. The structure allowed U.S. multinationals to take advantage of tax benefits available under both Dutch and Irish law.

${ }^{79}$ See Shu-Yi Oei \& Diane M. Ring, Leak-Driven Law, 65 UCLA L. REV. 532 (2018) (detailing the disclosure and media attention). See also Arthur J. Cockfield, Big Data and Tax Haven Secrecy, 18 Fla. TAx Rev. 483 (2016) (discussing information gleaned from tax haven data leaks).

${ }^{80}$ Such ordinary rulings included confirmation of requesting entities' status as Luxembourg tax residents. See Marian, supra note 47.

81 Id. at 31 (claiming that Luxembourg would accede to the "whim" of taxpayers as to debt or equity classifications). 
governments were complicit in helping companies to avoid tax. ${ }^{82}$ Suddenly, international tax became not only dinner party conversation but also the subject of protests in the street. In light of this "mainstreaming" 83 of international tax, the G20 countries needed to do something — or at least appear to do something — about corporate tax avoidance. In 2012, the G20 leaders expressed strong support for international cooperation to combat tax avoidance. ${ }^{84}$ Lacking a permanent staff, the G20 delegated to the OECD the task of coordinating multilateral efforts, initiating the BEPS Project. ${ }^{85}$ Within months, the OECD issued an ambitious Action Plan identifying fifteen areas of corporate tax needing reform. ${ }^{86}$ The goal of BEPS was to combat profit shifting, ostensibly by "align[ing] . . returns with value creation." ${ }^{87}$ The improbable deadline for most of the project was just two years, during which the G20 and OECD countries envisioned agreeing to coordinated solutions. ${ }^{88}$ Stakeholders predicted that the OECD would fail to meet the deadlines to deliver draft BEPS proposals, and that, even if the OECD did meet its deadlines, the project would not result in significant changes. ${ }^{89}$ These were safe predictions.

In addition to the revenue pressure created by the global financial crisis and the popular backlash from new revelations of aggressive corporate tax planning, events leading up to BEPS facilitated states' efforts to coordinate their responses to corporate tax abuse. For example, in 2011, to better respond to the financial crisis, the G20 had shifted from a meeting of finance ministers and central bankers to one of national leaders. The G20 closely followed and strongly backed progress on BEPS, ${ }^{90}$ enabling OECD officials to expand their own authority by claiming they had a "mandate" from the G20.91

${ }^{82}$ See, e.g., Eur. Parliament News, Tax Avoidance: MEPs Accuse Council of Undermining EU's Credibility (Feb. 1 , 2018) at http://www.europarl.europa.eu/news/en/headlines/priorities/taxes/20180126STO94140/tax-avoidance-meps-accuse-council-of-undermining-eu-s-credibility (quoting Member of European Parliament Ana Gomes as stating that corporate tax avoidance "fuels populism and discredits our governments, political parties and public institutions").

${ }^{83}$ See Manal S. Corwin, Sense and Sensibility: The Policy and Politics of BEPS, 145 TAX Notes 133, 143 (Oct. 6, 2014) (using the term to describe increased scrutiny of international tax by the public and politicians).

${ }^{84}$ G20, Leaders' Declaration, Los Cabos, Mexico, para. 48 (2012). ("we reiterate the need to prevent base erosion and profit shifting").

85 OeCD, Action Plan on Base Erosion and Profit Shifting 11 (2013) [hereinafter Beps Action Plan]. This phenomenon is part of a larger trend. See Jan Wouters \& Sven Van Kerckhoven, The OECD and the G20: An Ever Closer Relationship?, 43 Geo. Wash. InT'L L. Rev. 345, 346 (2011); Allison Christians, Taxation in a Time of Crisis: Policy Leadership from the OECD to the G20, 5 Nw. J. L. \& SoC. POL. 19 (2010).

86 BEPS ACTION PLAN, supra note 85.

${ }^{87} \mathrm{Id}$. at 20.

$88 \mathrm{Id}$. at $24-25$.

${ }^{89}$ See, e.g., Amanda Athanasiou \& Margaret Burow, William Morris and Carol Doran Klein-BEPS and Business, 76 Tax Notes Int'L 1058 (Dec. 22, 2014) (quoting Will Morris of the OECD's Business and Industry Advisory Committee as stating that "a lot of people thought" that "a disparate group of countries" could not hold together).

90 See Itai Grinberg, The New International Tax Diplomacy, 104 GEo. L.J. 1137, 1146-52 (2016) (discussing involvement of G20).

${ }^{91}$ See, e.g., Camille Prigent, Interview with Pascal Saint-Amans (Aug. 29, 2017), available at https://www.leadersleague.com/en/news/pascal-saint-amans-oecd-project-beps-was-a-political-necessity (quoting the head of tax for the OECD as stating "We started to consider the idea of such a project in 2012, then obtained a mandate from the G20 in 2013.”). 
Likewise, successes in multilateral tax cooperation at the OECD on tax information-sharing and enforcement in the immediate pre-BEPS era paved the way for cooperation on corporate tax avoidance by increasing confidence regarding compliance and monitoring. ${ }^{92}$

The late twentieth and early twenty-first centuries also saw a dramatic expansion of the role of EU institutions in international tax. The EU promotes tax cooperation in several ways. First, the ability of the member states to pool their sovereignty and the role of the Commission in advocating pan-European interests has enabled the EU to serve as an important counterweight to the United States in international tax relations, including by forcing the United States to the bargaining table on important issues such as the taxation of digital companies. ${ }^{93}$ Second, EU-level legislation provides a streamlined and simultaneous way to implement agreed reforms in all member states, reducing the risk of defection. ${ }^{94}$ Third, EU-level tax policymaking increases opportunities for issue linkage - that is, it increases opportunities to bargain across policy areas and time periods. Fourth, by threatening to use its enforcement powers to undo coordinated-but malleable_-standards, such as the arm's-length transferpricing method, the Commission may have encouraged EU member states to cooperate at the OECD to forestall deeper Commission involvement in tax administration. ${ }^{95}$ At the same time, the threat that the Commission might undermine or replace the arm's-length standard also motivated non-EU member states-especially the United States - to devise cooperative solutions that could discourage the EU from taking a greater role in tax policy. ${ }^{96}$

These shifts in the economic, political, and institutional landscape overcame barriers to cooperation. The technical ability and policy ambition of OECD staff, the political resolve and crisis-fueled revenue needs in the OECD and G20 states, and voter dissatisfaction with corporate tax dodging proved a potent combination. Over the next two years, tax officials from the OECD and G20 countries hammered out proposals to curb aggressive tax planning, close tax gaps, and increase states' ability to monitor both multinationals and each other through various tax transparency measures. ${ }^{97}$ Skillful leadership at the OECD and participating states' willingness to dedicate significant technical and political resources to finding pragmatic solutions meant that the OECD met its deadlines, generating reports and deliverables on every action item in just two-and-a-half years. ${ }^{98}$

\section{The Transformation of International TaX}

As noted in the introduction, many observers understand BEPS as merely a gap-filling project that patched technical rules while missing the opportunity for fundamental reform. This

\footnotetext{
${ }^{92}$ For more on information-sharing and curbing tax avoidance and competition, see Ault, supra note 64; AviYonah, supra note 62.

${ }^{93}$ For more on EU-U.S. tax relations, see Part III.F.2 infra.

${ }^{94}$ Implementation at the EU level means that EU sanctions would be available for use against defectors. It also means that any taxpayer-favorable measures adopted as EU directives would have direct effect, even without national enabling legislation.

${ }^{95}$ For the Commission's misadventures in transfer-pricing administration, see Ruth Mason, State Aid Special Report_Part 4: Whose Arm's Length Standard?, 155 TAX NOTES 947 (2017).

96 See discussion in note 125 infra.

97 OECD/G20, BEPS Project Explanatory Statement (2016) [hereinafter 2016 BEPS Explanatory STATEMENT] (briefly explaining the project and its recommendations).

${ }^{98} \mathrm{Id}$.
} 
Part argues that this view fails to recognize the potentially profound effect of BEPS on the decisionmakers, agendas, institutions, norms, and legal forms of international tax. ${ }^{99}$

\section{A. New Participants in Multilateral Tax Policymaking}

The BEPS Project brought the G20 and OECD countries together "on an equal footing" 100 to make international tax policy. The OECD - a group that only recently reached thirty-seven members ${ }^{101}$ - long has been criticized for excluding other countries from international tax policy decisions. ${ }^{102}$ The G20 added to the OECD eight additional countries-Argentina, Brazil, China, India, Indonesia, Russia, Saudi Arabia, and South Africa. ${ }^{103}$ These countries collectively have a population of over 3.5 billion and they bring to the OECD a developing-country perspective that was sorely lacking. ${ }^{104}$ Moreover, as negotiators finalized the BEPS recommendations, the G20 insisted that the OECD take an inclusive approach, inviting more countries into the post-BEPS monitoring and standard-setting process. The BEPS Inclusive Framework was established; its membership currently stands at 137 states. ${ }^{105}$ The Inclusive Framework is open to countries that commit to implementing the BEPS minimum standards. ${ }^{106}$

Nongovernmental organizations (NGOs) have also taken on an increasingly prominent role in tax policymaking, including in forums provided by the OECD, such as various public discussion sessions and open invitations for public commentary that were held regarding each action item. ${ }^{107}$ Watchdog groups, such as the Tax Justice Network and the BEPS Monitoring Group, emerged to attempt to influence the outcome of BEPS. ${ }^{108}$

Although they perhaps cannot properly be called participants in the policymaking process, journalists, including the International Consortium of Investigative Journalists that revealed the global scale of tax evasion and corporate-tax avoidance, ${ }^{109}$ galvanized popular attention and helped make reform possible.

\footnotetext{
${ }^{99}$ For criticism of BEPS, see references in note 1 supra.

1002016 BEPS EXPLANATORY STATEMENT, supra note 97, at 4.

${ }^{101}$ OECD, Global Reach, at https://www.oecd.org/about/members-and-partners.

102 See, e.g., Christians, supra note 1, at 1604; Tarcísio Diniz Magalhães, What Is Really Wrong with Global Tax Governance and How to Properly Fix It, 10 World TAX J. 4 (2018) (criticizing the OECD's closed-club model of decision making).

${ }^{103}$ G20, G20 Participants, at https://g20.org/en/about/Pages/Participants.aspx. The remainder of the G20Australia, Canada, France, Germany, Italy, Japan, Republic of Korea, Mexico, Turkey, the United Kingdom, and the United States-were already OECD members. Compare id. with OECD, Member Countries, at http://www. oecd.org/about/members-and-partners. The European Union is a nonvoting participant at the OECD and a full member of the G20.

${ }^{104}$ See United Nations, World Economic Situation and Prospects, at 1 (2019) (labeling as developing economies Argentina, Brazil, China, India, Indonesia, Saudi Arabia, and South Africa. It labeled Russia as an economy in transition.). Because the G20 consists of high-GDP countries, however, even with the G20, the OECD still lacks important perspectives. See also UN Population Dashboard, at https://www.unfpa.org/data/world-populationdashboard (providing populations of each country in 2019).

105 OECD, Members of the OECD/G20 Inclusive Framework on BEPS, available at https://www.oecd.org/tax/ beps/inclusive-framework-on-beps-composition.pdf.

${ }^{106}$ OECD, Background Brief: InClusive Framework on BEPS 11 (2017) [hereinafter InClusive Framework BRIEF]. For more on the BEPS minimum standards, see Part III.C infra.

107 See Oei \& Ring, supra note 79 (in part criticizing this development).

${ }^{108}$ On participation by NGOs, see Christians, supra note 1, at 1603.

${ }^{109}$ Oei \& Ring, supra note 79.
} 


\section{B. Expanded Role for Multilateralism and the OECD}

\section{International Tax Agenda}

Dominated by the United States for the better part of a century, the work of the tax division of the OECD prior to BEPS was the stuff of technical experts - of geeks, not diplomats. ${ }^{110}$ BEPS expanded the international tax policy agenda, including by making extensive recommendations for changes to domestic law. ${ }^{111}$ This was true for some of the minimum standards that emerged from BEPS, such as administrative-ruling disclosure and country-by-country reporting, ${ }^{112}$ as well as certain non-minimum standards, including the interest-deductibility and anti-hybrid rules. ${ }^{113}$ As will be discussed later, the agenda of the Inclusive Framework has now moved well beyond BEPS to how to redistribute the entitlement to tax income from cross-border commerce. ${ }^{114}$

\section{Role of the $O E C D$}

One important aspect of international tax policymaking has not changed: the dominance of the OECD as a forum. ${ }^{115}$ The role and budget of the organization have expanded along with the composition of the decisionmakers and the agenda of international tax. ${ }^{116}$ BEPS enabled the OECD to leverage its technical tax expertise into a broad mandate to guide international tax reform efforts - not only for its own thirty-seven members, but for over a hundred nonmember countries. The OECD facilitates international cooperation by providing deep technical expertise, effective monitoring of state compliance with agreements, and a forum for iterated negotiations that also allows for issue linkage.

110 See H. David Rosenbloom \& Stanley I. Langbein, United States Tax Treaty Policy: An Overview, 19 Colum. J. Transnat'L L. 359, 367-69 (1981) (giving history of OECD standards).

${ }^{111}$ See, e.g., Richard Collier, Stef van Weeghel, Phil Greenfield, Pam Olson, John Steveni \& Matthew Chen, OECD Recommendations on BEPS 2014 Deliverables: Few Surprises But No Let Up, 25 J. INT'L TAX'N 25, 25 (2014) ("To the extent that the changes relate to the OECD's Model Tax Convention and Transfer Pricing Guidelines, their implementation is assured and should follow fairly quickly.").

112 See Inclusive Framework, Progress Report 19 (2018) [hereinafter 2018 BEPS Progress Report].

$113 \mathrm{Id}$. at 25.

114 See discussion in Part III.F infra.

115 Perhaps no example better highlights the dramatic elevation of the OECD than its release, expressly under its own authorship, of a proposed "unified approach" to dividing tax entitlements among states. OECD, Secretariat Proposal for a "Unified Approach" Under Pillar One (2019) [hereinafter Secretariat Proposal]. Part IV discusses this initiative.

116 The OECD budget for tax rose from about $€ 12$ million in 2013 to nearly $€ 20$ million in 2018 . Compare OECD, Financial Statements of the OECD as of 31 December 2018, at 52 (listing budget for the "taxation" "output group") with OECD, Financial Statements of the OECD as of 31 December 2013 (same). The 2018 budget did not separately state costs associated with BEPS. In 2018, over $€ 12$ million of the tax-output-group budget consisted of "voluntary contributions," made outside the "assessed contribution" framework that constitutes the OECD's regular budget. Assessed contributions include a flat contribution from each state and a contribution that increases with GDP. In 2019, the U.S. share of the assessed part of the budget was $20.5 \%$ of the total $€ 202.5$ million assessed contribution. Also in 2019, the voluntary contributions across all areas totaled $€ 105$ million. See OECD, Member Countries' Budget Contributions for 2019, at http://www.oecd.org/about/budget/member-countries-budget-contributions.htm. The public document does not reveal the U.S. share of the voluntary contributions. Id. Voluntary contributions fund particular programs of work, but the financial statement does not indicate which countries made the voluntary contributions or for which projects, although the budget for the Global Forum on Transparency was listed at over $€ 8$ million. 


\section{Acceptance of Full Taxation as a Norm}

Before BEPS, cooperation in international tax aimed principally to lower transaction costs for cross-border economic actors by preventing double taxation, reducing compliance costs for companies, and providing legal mechanisms to resolve disputes between taxpayers and tax administrations. ${ }^{117}$ States overcomplied with the no-double-tax norm, resulting in widespread nontaxation of income. ${ }^{18}$ Today, however, states increasingly support not only a no-double-tax norm, but also what this Article will call a "full taxation" norm that dictates that all of a company's income should be taxed in places where it has real business activities. ${ }^{119}$ Full taxation is a shorthand that encompasses other frequently used terms that aim at the same idea, including "prevention of profit shifting," prevention of "aggressive" or "abusive" tax planning, closing of "loopholes" or "gaps," and the particularly inelegant "prevention of double nontaxation." 120 In the content and form of its recommendations, BEPS both confirmed and operationalized full taxation as a new international tax norm. This section explains how the BEPS proposals endorsed full taxation.

The BEPS Project resulted in two kinds of recommendations: discretionary reforms and minimum standards, the latter of which the states participating in the Inclusive Framework agreed to implement. ${ }^{121}$ Nearly all of the BEPS recommendations-and three out of four of its minimum standards_ - aim to secure full taxation. ${ }^{122}$ For example, one minimum standard promotes tax transparency through several related measures, including by requiring countryby-country reporting. Before BEPS, companies reported to a state only profits and activities that took place in that state. Tax administrators lacked a complete picture of a multinational's global activities, which limited their ability to identify, let alone combat, income shifting and

117 See BEPS Action PLAN, supra note 85, at 9 (prior to BEPS “sovereign states have co-operated to ensure coherence in a narrow field, namely, to prevent double taxation”).

${ }^{118}$ Cf. Philipp Genschel \& Thomas Rixen, Settling and Unsettling the Transnational Legal Order of International Taxation, in Transnational Legal Orders 154, 157 (Terence C. Halliday \& Gregory Shaffer eds., 2015) ("double tax relief endogenously breeds tax competition").

119 "Full taxation" can be understood as an element of Reuven Avi-Yonah's "single-tax principle," which implies two sub-rules: (1) full taxation and (2) prevention of double taxation. See discussion in text accompanying notes 136-138 infra.

${ }^{120}$ Such terms frequently appear in the BEPS materials and elsewhere without being defined. See, e.g., BEPS ACTION Plan, supra note 85, at 13 ("prevent double non-taxation"); id. ("cases of no or low taxation associated with practices that artificially segregate taxable income from the activities that generate it."); id. at 8 ("MNEs that have the ability to shift their profits across borders to avoid or reduce tax"); id. at 22 ("aggressive or abusive transactions"). Commentators likewise frequently use these terms, often acknowledging lack of satisfying definitions for them. See, e.g., Brauner, supra note 1, at 1036 (critically analyzing "double non-taxation" and the puzzles it raises). See, e.g., Leopoldo Parada, Hybrid Entity Mismatches and the International Trend of Matching Tax Outcomes: A Critical Approach, 46 INTERTAX 971, 971 (2018) (critical of the "assumption that income should be taxed somewhere-no matter where”); $c f$. Ruth Mason \& Michael S. Knoll, What Is Tax Discrimination?, 121 Yale L.J. 1014 (2012) (criticizing the concepts of "once, somewhere," "double benefit," and "double burden").

${ }^{121}$ OECD, BEPS EXECUTIVE SumMaries (2015) (summarizing outcomes) [hereinafter BEPS ExeCUTIVE SUMMARIES]. This discussion of the BEPS outcomes draws extensively on OECD reports on BEPS, which amount to thousands of pages. See, e.g., 2016 BEPS Explanatory STATEMENT, supra note 97, InClusive FrameWORK, Progress Report (2019); 2018 BePS Progress Report, supra note 112; Inclusive Framework, Progress Report (2017). The OECD also issued multiple reports on each of fifteen action items. See, e.g., INCLUSIVE Framework, Neutralising the Effects of Branch Mismatch Arrangements, Action 2 (2017) [hereinafter BEPS Hybrid MisMATCH RePORT]

122 See, e.g., BEPS Action PLAN, supra note 85, at 10 ("BEPS relates chiefly to instances where the interaction of different tax rules leads to double non-taxation or less than single taxation."). 
stateless-income planning. Multinationals must now submit country-by-country reports, which provide governments a global and per-country overview of profits, sales, employees, income, and where companies declare income and pay taxes. ${ }^{123}$ These reports aid tax administrators in assessing whether companies shift profits; the reports can therefore help target enforcement activity. By heightening audit, litigation, and reputational risks for companies showing large profits in havens (or nowhere), the reports presumably will discourage profit shifting.

Another aspect of this minimum standard requires BEPS states to automatically forward to each other summaries of certain previously secret unilateral administrative tax rulings, including rulings applying the notoriously flexible arm's-length standard. ${ }^{124}$ Before BEPS, a taxpayer could secure a ruling from State $A$ in which the state agreed not to tax certain income because that income was more properly allocated to State B. But nothing forced the taxpayer to declare the income in State B. Thus, taxpayers could take inconsistent positions in different states about the same income. The exchange of tax rulings give states notice of administrative decisions made elsewhere that may affect domestic tax liability; it also limits taxpayers' planning options. By increasing transparency, the exchange of rulings also reduces incentives for states to collude with taxpayers trying to avoid foreign tax. ${ }^{125}$

A second minimum standard pursues full taxation by enhancing efforts to prevent abuse of tax treaties. For example, states agreed to change the preamble of tax treaties to reflect that their purpose is not merely to avoid double taxation, but also to prevent tax evasion and avoidance. ${ }^{126}$ Likewise, states agreed to include stronger anti-abuse rules in their treaties. ${ }^{127} \mathrm{~A}$ third minimum standard seeks to curb harmful tax competition by demanding a closer connection between business activities and entitlements to tax benefits. ${ }^{128}$ Taxpayers must have "substantial activities" in a jurisdiction before they can receive certain tax preferences there. This prevents income shifting by limiting divergence between where a business conducts its activities and where it declares its income, including by limiting special low-tax "patent

\footnotetext{
${ }^{123}$ Country-by-country reporting applies to multinationals with $€ 750$ million in annual consolidated revenue. Transfer Pricing Guidelines, supra note 15, at 242.

124 See G20/OECD, Countering Harmful Tax Practices More Effectively, Taking into Account Transparency and Substance: BEPS Action 5 Report (2015) [hereinafter BePS Action 5 Report] Countries receiving summaries can request the full ruling in a second step. $I d$. at 54 .

125 Transparency does not, by itself, ensure tax, although it supplies much-needed information to states interested in closing tax gaps. Leandra Lederman \& Joseph C. Dugan, Information Matters in Tax Enforcement, 2020 B.Y.U. L. ReV., at 14-18, available at http://ssrn.com/abstract=3325598 (forthcoming 2020). BEPS rulings exchange served an additional strategic purpose: to put the Commission out of the business of reviewing rulings granted by EU member states. Aware of the potential problems with confidential tax rulings, the Commission launched an investigation of member state ruling practices; it exposed cozy deals between states and taxpayers. See Mason, supra note 47. To cure what it saw as illegal subsidies, however, the Commission sought to impose its own arm's-length standard that would compete with the OECD arm's-length standard. The rulings-exchange regime negotiated as part of BEPS and ultimately implemented by the EU—a regime which the Commission was denied access - can be understood as an effort to ward off further intrusive state-aid investigations of member state ruling practices. The BEPS rulings-exchange regime also supplied the Commission a face-saving exit strategy from its bruising state-aid battle with the United States. For more on that controversy, see id. and Part IV infra.

126 The Model preamble now states that the contracting states intend "to conclude a Convention for the elimination of double taxation ... without creating opportunities for non-taxation or reduced taxation through tax evasion or avoidance." OECD MODEL, supra note 6 (emphasis added to denote changes).

127 OECD, 2016 BEPS EXPLANATORY STATEMENT, supra note 97, at 14-15.

128 See generally BEPS ACTION 5 REPORT, supra note 124.
} 
boxes." 129 Under a fourth minimum standard - the only one aimed primarily at preventing double taxation, rather than ensuring full taxation-states agreed to improve tax-treaty dispute resolution mechanisms. ${ }^{130}$

Although not representing minimum standards, other BEPS reforms-including revised transfer-pricing rules - aim to ensure full taxation by reducing opportunities for profit shifting. ${ }^{131} \mathrm{BEPS}$ also closes stubborn loopholes. For example, its anti-hybrid rules help combat the U.S. check-the-box rules, which the United States retained. Countries also developed model interest-deductibility rules and a set of best practices for CFC rules ${ }^{132}$ that aim to reduce profit shifting. ${ }^{133}$ Although not formally part of the BEPS Project, Ireland succumbed to pressure to change its tax-residence rule that facilitated Apple's stateless income planning. ${ }^{134}$

Commentators analyzing individual BEPS recommendations may reasonably conclude that none is by itself transformative. Yariv Brauner, for example, criticized the OECD for failing to "include a clear articulation of double non-taxation as a fundamental principle of the international tax regime." 135 Taken collectively, however, the BEPS recommendations reflect not only an extraordinary new commitment to coordinating domestic tax rules, but also an unprecedented commitment to full taxation.

Because states already faithfully adhered to the no-double-tax norm, growing acceptance of full taxation as a goal of international tax brings states closer to implementing Reuven Avi-Yonah's "single-tax principle," which requires income to be taxed exactly once, no more and no less. ${ }^{136}$ Unfortunately, like its foil "no double taxation," the concept of "full taxation" is underspecified. While the notion that a company should be subject to "full" but not "double" taxation seems unobjectionable, because there is no global benchmark for defining taxable income and because there is no ideal tax rate, views diverge as to when these standards have been met. ${ }^{137}$ Despite

129 "Patent box" is a term used to describe any of a wide range of tax benefits awarded to income from intellectual property. 2016 BEPS EXPLANATORY STATEMENT, supra note 97, at 14.

130 See generally OECD, Making Dispute Resolution Mechanisms More Effective, Action 14 Final REPORT (2015).

1312016 BEPS EXPLANATORY STATEMENT, supra note 97, at 15-16 (taking a more substantive approach to allocating income among group members). Although changes to the transfer-pricing rules are not minimum standards, because many states dynamically incorporate the OECD Transfer-Pricing Guidelines, those changes will filter into to domestic law. See generally Richard Collier \& Joseph Andrus: Transfer Pricing and the Arm's Length Principle After BEPS (2017).

${ }^{132}$ For an explanation of CFC rules, see text accompanying note 33 supra.

133 BEPS EXPLANATORY STATEMENT, supra note 97, at 13-14.

134 See Danny Hakim, Europe Takes Aim at Deals Created to Escape Taxes, N.Y. Times (Nov. 14, 2014).

135 See, e.g., Brauner, supra note 1, at 996 (arguing that the OECD should have clearly articulated that "the whole BEPS project is about double non-taxation").

${ }^{136}$ Under Avi-Yonah's formulation of the "Single Tax Principle," "income from cross-border transactions should be subject to tax once ... at the rate of tax . . . determined by [the Benefits Principle]." Reuven S. AviYonah, International Taxation of Electronic Commerce, 52 TAX L. REV. 507, 517 (1997). The "benefits principle" is the idea that states derive entitlement to tax based on benefits they provide to taxpayers.

137 To fully specify single taxation, including both its full-tax and no-double-tax elements, requires specifying a distributive rule for determining which state or states will tax a multinational's income. Avi-Yonah adopts as the distributive rule for his single-tax principle the "benefits principle," as instantiated in the tax-treaty bargain negotiated in the 1920s, which "assigns the right to tax active (business) income primarily to the source jurisdictions, while the right to tax passive (investment) income is assigned primarily to the residence jurisdictions." Id. at 509. Although the benefits principle generally would lead to taxation by states in which multinationals have productive 
its intuitive appeal, the concept of full taxation raises a number of problems that will be explored further below. ${ }^{138}$

\section{Novel Legal Forms}

BEPS required multilateral tax cooperation on a scale never seen before. But it did notnor was it expected to-result in the genesis of new supranational tax institutions that could adjudicate tax disputes or legislate tax policy. Acknowledgments by public officials of states' inability to "go it alone" in international tax became commonplace in the BEPS era, ${ }^{139}$ but officials remained reluctant to breach the last bastion of national sovereignty. For example, at a recent press conference with U.S. Treasury Secretary Steven Mnuchin, French Finance Minister Bruno Le Maire declared, "Let's accelerate work at an international level." ${ }^{140}$ But when asked about France's recent adoption of unilateral digital taxes that arguably discriminate against U.S. companies, Le Maire retorted, "France is a sovereign nation that decides its own tax rules." 141 These comments reflect a tension between the growing need for states to cooperate to achieve shared goals and their reluctance to relinquish exclusive national control over taxation.

To coordinate action in the areas where they agreed, while simultaneously protecting their core tax prerogatives, the BEPS states relied on innovative legal forms that avoided the "fashionable despair" of multilateral tax cooperation. ${ }^{142}$ Some of these legal forms-such as peer review and soft law measures - are familiar to international law and have been used previously by OECD tax initiatives. But others are novel, including the Multilateral Instrument that modifies bilateral tax treaties. States also relied on what this Article calls "fiscal fail-safes," in which the failure of one state to tax triggers tax by another state, thereby assuring full taxation. Although unilateral fiscal fail-safes were previously found in domestic law, coordinated implementation of harmonized fiscal fail-safes enabled BEPS countries to more effectively achieve full-tax goals by deterring both state defection and aggressive tax planning.

\section{The Multilateral Instrument}

Some BEPS recommendations required changes to bilateral tax treaties. To implement these changes expeditiously without renegotiating thousands of bilateral treaties, the BEPS

factors, as Avi-Yonah acknowledges, the benefits principle does not indicate precisely how multiple states providing benefits to the same taxpayer should share entitlement to tax a multinational's income. Id. at 522.

${ }_{138}$ See Part III.E infra.

139 See, e.g., Commission Communication, supra note 48, at 1 ("a purely national approach to taxation no longer works"); José Antonio Alonso, United Nations Department of Economic and Social Affairs, Committee for Development Policy, International Tax Cooperation and Sovereign Debt Crisis Resolution: Reforming Global Governance to Ensure No One Is Left Behind, at 10 (May 2018), available at https:/www.un.org/development/ $\mathrm{des} / \mathrm{dpad} / \mathrm{wp}$-content/uploads/sites/45/publication/CDP-bp-2018-41.pdf ("Stopping international tax evasion and abusive tax avoidance practices requires a cooperative response at a global level.").

${ }^{140}$ Sam Schechner \& Paul Hannon, France Presses on with Digital Tax Despite U.S. Probe, WaLl St. J. (July 11, 2019).

${ }^{141}$ Liz Alderman, France Moves to Tax Tech Giants, Stoking Fight with White House, N.Y. Times, (July 11, 2019) (quoting Le Maire at the same press conference).

${ }^{142}$ Avi-Yonah, supra note 41, at 1349. 
countries invented a new international law instrument. ${ }^{143}$ Signed in June 2017, the Multilateral Convention to Implement Tax Treaty Related Measures to Prevent BEPS ${ }^{144}$ amends and updates the signatories' bilateral tax treaties without supplanting them. ${ }^{145}$ With eighty-eight signatories so far, the Multilateral Instrument will impact over 1,500 tax treaties. ${ }^{146}$ It provides a way for participating countries to quickly implement certain BEPS minimum standards ${ }^{147}$ and other BEPS recommendations. ${ }^{148}$ By leaving preexisting bilateral treaties intact, while updating them, the Multilateral Instrument embodies the pragmatic innovation and accommodation of sovereignty concerns that typified BEPS. ${ }^{149}$ It also may represent a significant step toward, and a proving ground for, a more ambitious multilateral tax treaty. Although the Multilateral Instrument has detractors, ${ }^{150}$ and the United States is not a signatory, ${ }^{151}$ most recognize that it has, as Allison Christians put it, the "potential to permanently alter the architecture of international tax relations." 152

\section{Coordinated Unilateralism}

BEPS, and international tax more generally, follows a long tradition of what might be called coordinated unilateralism. ${ }^{153}$ Coordinated unilateralism includes nonbinding standards that reflect pooled technical expertise, are set cooperatively, and are implemented via domestic law or administrative regulation rather than a treaty. Many BEPS recommendations

143 See OECD, Explanatory Statement to the Multilateral Convention to Implement Tax Treaty Related Measures to Prevent Base Erosion and Profit Shifting 1 (2018) [hereinafter MLi Explanatory STATEMENT] ("the sheer number of bilateral treaties (more than 3000) would make bilateral updates to the treaty network burdensome and time-consuming, limiting the effectiveness of multilateral efforts").

${ }^{144}$ Multilateral Convention to Implement Tax Treaty Related Measures to Prevent Beps, available at http://www.oecd.org/tax/treaties/multilateral-convention-to-implement-tax-treaty-related-measures-to-preventbeps.htm [hereinafter MLI].

145 To determine the content of a bilateral tax treaty between two countries, both of which are parties to the MLI, one must look to the MLI to see which of its provisions, if any, the two countries agreed should supersede or augment the provisions of their preexisting bilateral tax treaty.

146 OECD, OECD Secretary-General Tax Report to G20 Leaders, Osaka, Japan, at 16 (2019).

${ }^{147}$ Namely, the recommendations for modifications to bilateral tax treaties. See, e.g., MLI, supra note 144, Art. 7 (anti-abuse provisions).

${ }^{148}$ MLI EXPLANATORY STATEMENT, supra note 143, at 4 ("Where a substantive provision does not reflect a minimum standard, a Party is generally given the flexibility to opt out of that provision entirely."); see, e.g., MLI, supra note 144, Art. 3 (rules to combat hybrid mismatches); Art. 4 (anti-abuse rule for corporate dual residents).

149 The MLI accommodates sovereignty concerns through optionality, which is available for both substantive provisions and covered bilateral relationships.

${ }^{150}$ Azam, supra note 1, at 584 (“[I] do not see [the MLI] as a revolutionary moment"); Avi-Yonah \& Xu, supra note 1, at 234 (observing that "many countries will be not interested in participation" and that the UN would be a better forum than the OECD for such cooperation).

${ }^{151}$ The failure of the United States to sign is not as bad as it sounds because the minimum standards in the MLI were already in the U.S. Model and its treaties, and therefore the United States did not need the MLI to make its treaties BEPS-compliant.

${ }^{152}$ Christians, supra note 1 , at 1641.

${ }^{153}$ Use of the term coordinated unilateralism is intended to sidestep academic debates on the meaning and meaningfulness of "soft law" as a form of law. See, e.g., Kal Raustiala, Form and Substance in International Agreements, 99 AJIL 581, 596 (2005) ("soft law is not a coherent concept"). Cooperation among the OECD countries long has generated widely accepted guidelines for bilateral tax treaties and for interpretations of tax standards developed cooperatively at the OECD. The OECD and Council of Europe also developed a multilateral treaty on tax administrative matters, the Convention on Mutual Administrative Assistance in Tax Matters, that has 136 participants. The United States signed, but did not ratify, the Convention. See generally Azam, supra note 1, at 543-46. 
involve coordinated modifications to domestic law, including the model interest-deductibility, anti-hybrid, CFC, and various disclosure rules. ${ }^{154}$ Other BEPS recommendations were implemented partly through treaties, and partly through domestic law. For example, countryby-country reporting, a BEPS minimum standard, required both domestic reporting infrastructure and new treaties or treaty provisions to exchange the reports. ${ }^{155}$

As others have observed, ${ }^{156}$ coordinating domestic rules may reduce or circumvent domestic opposition to international cooperation, by, among other things, lowering the stakes of cooperation. ${ }^{157}$ This could be particularly important for states uncertain of whether they will be able to build capacity to comply with some of the more onerous BEPS standards. ${ }^{158}$ Coordinated unilateralism also leverages the ability of tax administrations to implement policy without enlisting other parts of government. For example, the U.S. Treasury Department took the position that it had authority to implement country-by-country reporting without specific enabling legislation or a new treaty. ${ }^{159}$ Such coordinated administrative action facilitates cooperation by enabling domestic legislators to avoid costly votes in favor of stricter tax standards that are likely to be unpopular with corporate campaign donors.

Coordinated unilateralism makes sense for policies that are known to be more effective if more states adopt them, including any policy that generates network effects. Tax treaties themselves exhibit network effects, ${ }^{160}$ as do many of the BEPS recommendations, including tax-rulings exchange, country-by-country reporting, anti-abuse rules, CFC regimes, and more. ${ }^{161}$ As network effects accrue, benefits from cooperation increase. By facilitating rolling implementation, coordinated unilateralism also facilitates later cooperation by countries for whom the benefits of joining only marginally exceed the costs.

${ }^{154}$ See BEPS EXECUTIVE SUMmaRIES, supra note 121. In other cases, such as modifications to the transfer-pricing rules or Commentary to the OECD Model, BEPS reforms were implemented in domestic law either by legislation that dynamically incorporates OECD standards or by administrative or judicial adoption of those standards.

155 Transfer Pricing Guidelines, supra note 15, 501-65.

156 See generally Kenneth W. Abbott \& Duncan Snidal, Hard and Soft Law in International Governance, 54 INT'L ORG. 421 (2000).

${ }^{157}$ Unlike withdrawing from a treaty, changes in domestic law typically do not jeopardize a state's credibility on the world stage.

${ }^{158}$ The BEPS recommendations themselves reflect acknowledgement of states' different tax capacities. For example, that only companies with $€ 750$ million in annual revenue must file country-by-country reports reflects a desire to minimize both compliance costs for smaller companies and enforcement costs for states with less tax capacity. 2016 BEPS EXPLANATORY STATEMENT, supra note 97, at 7.

159 See Treas. Reg. 1.6038-4 (2019) (claiming authority to implement country-by-country reporting). When Treasury implements reforms on its own, it averts domestic opposition that may arise if a different political party controls Congress.

160 See Eduardo A. Baistrocchi, The International Tax Regime and the BRIC World: Elements for a Theory, 33 Oxford J. Legal STud. 733 (2013); Tsilly Dagan, Tax Treaties as a Network Product, 41 Brook. J. InT'L L. 1081 (2016).

${ }^{161}$ For example, the benefits accruing to mandatory arbitration of tax disputes between tax administrations are more than linear. If two states commit to arbitration, then only bilateral disputes between those two states can be resolved through arbitration. If only one more state signs up, the number of covered bilateral relationships increases to three. Four participants cover six relationships, and so on. 


\section{Fiscal Fail-Safes}

BEPS facilitated the widespread adoption of a particular type of coordinated unilateral provision, which this Article will call "fiscal fail-safes." A fiscal fail-safe provides conditions under which if one country does not tax, another country fills the tax void. By automatically filling tax gaps - and thereby clawing back the benefit of tax planning and state-provided tax incentives - fiscal fail-safes discourage both aggressive tax planning and tax competition. The fiscal fail-safe concept unites a seemingly diverse and unrelated set of tax anti-abuse rules adopted both within and outside of BEPS. Fiscal fail-safes not only share a mechanism-linking triggers-but they also share a goal, namely, full taxation. Thus, the increasing prevalence of fiscal fail-safes both reflects and effectuates the growing acceptance of full taxation as a new global tax norm. ${ }^{162}$

The BEPS anti-hybrid rules exemplify the use of fiscal fail-safes to neutralize state defection from full-tax goals. Among other tasks, the anti-hybrid rules help defeat debt-equity arbitrage. ${ }^{163}$ Debt-equity arbitrage takes advantage of the fact that because debt and equity exist on a legal spectrum, states may take opposite views of the same financial instrument, with one state seeing debt where another sees equity. ${ }^{164}$ Such hybrid instruments can generate deductible interest when paid out of one jurisdiction, but excludable dividends when received in the other. ${ }^{165}$ When made between affiliates of the same corporate group, payments on such hybrid instruments generate deductions in one state with no corresponding inclusion in the other state. From a global perspective, hybrids thus make income disappear for tax purposes.

The BEPS solution to hybrids is a "primary rule" that directs the state from which the payment is made to deny an interest deduction unless the payment will be included in the recipient's state. ${ }^{166}$ Thus, the rule expressly links the tax treatment in one state to the tax treatment in another state. But what if the payer state is a jurisdiction that refuses to adopt the hybrid rules because it wants to help taxpayers to avoid tax? ${ }^{167}$ The BEPS recommendation includes a "defensive rule" to be applied by the recipient state, but only if the payer state does not-for whatever reason—shut down the hybrid. In that case, the defensive rule directs the recipient

162 Like amending preexisting tax treaties to implement anti-abuse rules, use of fiscal fail-safes comports with political economy predictions that incremental change to stable international institutions will take the form of "layering" or "conversion," rather than outright reform. Such layering reduces the risks to institutions compared to outright reform, and it may be easier to achieve than reform. Thomas Rixen, From Double Tax Avoidance to Tax Competition: Explaining the Institutional Trajectory of International Tax Governance, 18 Rev. INT'L POL. ECON. 197, 204 (2011) (discussing work of Kathleen Thelen).

${ }^{163}$ For more on arbitrage, Kane, supra note 53.

164 Some instruments are clearly debt, others clearly equity. But some instruments contain elements of both debt and equity, for example, "interest" payments may be tied to corporate performance, or "principal" may be repayable in stock.

165 The dividends would be excluded under many states' participation-exemption regimes for intercompany dividends.

166 See BEPS Hybrid Mismatch Report, supra note 121, at 23-44.

167 The notion that states would adopt tax laws or administrative practices to enable taxpayers to avoid foreign tax is realistic. See Kane, supra note 53 (exploring states' motives in creating arbitrage opportunities); Marian, supra note 47 (concluding from leaked evidence that Luxembourg used its tax administrative ruling process to "manufacture" bespoke mismatches for taxpayers). 
state to include the payment in the recipient's income. ${ }^{168}$ Each of these rules functions as a fiscal fail-safe; it fills what would otherwise be a cross-border tax gap. As long as at least one of the payer's state or the recipient's state adopts the BEPS anti-hybrid regime, the loophole will be closed, and the payment will be subject to tax. ${ }^{169}$ This kind of innovative, pragmatic problem-solving typified BEPS. Similar anti-hybrid rules counter hybrid entities, some of which arise from U.S. check-the-box rules. ${ }^{170}$

By triggering special tax treatment in cases of tax gaps, the hybrid rules enable states to soak up tax entitlement not exercised by another state. Thus, the primary and defensive rules enforce full taxation more effectively than would either rule by itself, and they work automatically, requiring no additional coordination between the states. Most importantly, by formulating the hybrid rules as a fiscal fail-safe, the BEPS states averted the need for states to harmonize their definitions of debt and equity. Instead of finding agreement on the thorny debt-equity distinction that has vexed generations of tax policymakers, the states merely agreed on a result - full taxation — and a method of achieving it.

By averting the need to harmonize definitions of debt and equity, the hybrid rules also made tractable a previously intractable tax arbitrage problem. Debt-equity arbitrage arose from two different kinds of failures to cooperate. First, high-tax states were unwilling to defer to each other or to collective judgement about what distinguished debt from equityeven though doing so would curb arbitrage. These states were not using their definitions of debt and equity as a vector of tax competition; instead, those definitions addressed domestic tax concerns that swamped international tax concerns. These states' refusal to coordinate opened an unintended tax gap.

The second type of gap was intentional. Other states essentially sold their sovereign ability to deem instruments to be either debt or equity for the specific purpose of facilitating tax abuse. By commercializing their sovereignty, these states encouraged taxpayers to locate hybrid instruments within their respective jurisdictions, where they generated at least some tax revenue. ${ }^{171}$ In effect, these states competed for paper profits. The states that opened gaps unintentionally and those that did so intentionally could not be expected to agree on a single conception of the debt-equity distinction, but the motivation of each type of state differed. The states that created unintended gaps had a common interest in defeating intentional gaps opened by the second set of states. By agreeing to a fiscal fail-safe that would close gaps without requiring harmonization of debt-equity distinctions, the first set of states could eliminate the gains redounding to the states that intentionally created gaps. If structured properly, anti-hybrid rules allow states of the first type to share revenue that otherwise would have been lost to states of the second type. At the same time, anti-hybrid rules make defection by states in the second group ineffective.

\footnotetext{
168 That is, the recipient state includes the payment, even if that state otherwise would regard the payment as exempt dividends.

${ }^{169}$ But see Leopoldo Parada, Double Non-taxation and the Use of Hybrid Entities: An Alternative Approach In THE New Era of BEPS 312-319, 343-352 (2018) (stressing the complexity of the rules and raisinge tax policy concerns, such as circularity, dependency on foreign laws, and economic double taxation).

${ }^{170}$ See BEPS Hybrid Mismatch RePORT, supra note 121, at 23-66.

${ }^{171}$ See, e.g., Marian, supra note 47 (describing in detail Luxembourg's debt-equity rulings practice).
} 
Several characteristics typify fiscal fail-safes. First, they include a mechanism to link tax treatment across countries. ${ }^{172}$ Second, fiscal fail-safes specify the conditions under which tax treatment in one state triggers a response in the other. Third, they specify special tax treatment, which constitutes a deviation from the implementing state's ordinary tax treatment of the relevant income (e.g., the state treats as taxable interest a payment that legally qualifies as a profit distribution). Fourth, the goal of the triggered treatment is normative; it aims to achieve full taxation or otherwise curb abuse. ${ }^{173}$

CFC rules, described above, function as fiscal fail-safes. Disclosure of information about tax rulings and country-by-country reporting also may act as fiscal fail-safes by providing states an opportunity to link their own tax treatment of a transaction to another state's treatment of the same transaction, thereby reducing the ability of taxpayers to take inconsistent positions in two states regarding the same income. ${ }^{174}$ But not all anti-abuse rules constitute fiscal fail-safes. Thin-capitalization rules, substance-over-form rules, limitations-on-benefits provisions, and many other anti-abuse rules fall outside the definition of fiscal fail-safes. ${ }^{175}$ And there may be more effective methods than fiscal fail-safes to achieve full taxation. For example, adopting a system that allocates income completely with no gaps-such as formulary apportionment-might better achieve full-tax goals. ${ }^{176}$ Given mismatched national regimes, however, fiscal fail-safes can be an effective way to bridge gaps.

Fiscal fail-safes may also take the form of administrative rules. For example, by building a regulatory fail-safe into the country-by-country reporting rules, the BEPS participants helped ensure speedy adoption, even by countries, such as the United States, that initially resisted the measure. ${ }^{177}$ Under the country-by-country reporting regime, a multinational must file certain reports with its headquarters state, but if its headquarters state does not participate in country-by-country reporting, then the company must file its report in another state in which it has a subsidiary, thereby reducing the possibility that a multinational could entirely avoid compliance with BEPS reporting requirements. Several business groups urged Treasury to allow taxpayers to elect to file country-by-country reports with the United States earlier than the deadline provided in U.S. law to avoid triggering the requirement that they file their report with another state's tax administration. ${ }^{178}$

One might object that fiscal fail-safes are not really new. Unilateral actions have always been available to respond to tax gaps and other strategic tax practices. Indeed, even before

\footnotetext{
${ }^{172}$ States also apply fiscal fail-safes to close domestic gaps, in which case the link might be between, for example, two different domestic taxpayers.

${ }^{173}$ As noted, the concept of full-taxation is incomplete without a distributive rule to supply the tax base or bases and rate or rates. See discussion in Part III.E infra.

${ }^{174}$ See BEPS ACTION 5 REPORT, supra note 12 (laying out the rulings-exchange regime).

${ }^{175}$ Fractional allocation methods, including two-sided transfer-pricing methods (such as profit splits) and formulary apportionment, are not fiscal fail-safes. Although they link tax treatment across states and aim at full tax, they involve no deviation from a state's normal rule.

${ }^{176}$ Even formulary apportionment might require fiscal fail-safes. For example, a revenue share could be allocated to a state that has productive factors, but that lacks jurisdiction to tax the income. In such cases, fiscal failsafes could provide rules for reallocating the untaxed share to the other taxing states, as in the "throw-around rules" found at the U.S.-state level.

${ }^{177}$ The United States resisted country-by-country reporting because U.S. officials feared the information in the reports would be used to allocate income according to factor presence, rather than arm's-length transfer pricing.

${ }^{178}$ See, e.g., Nat'l For. Trade Council, Letter to Mark J. Mazur, Asst. Sec. Treas. for Tax Policy, at 2-3 (Mar. 9 , 2016) (explaining that U.S. companies did not want to be obliged to file their reports outside the United States).
} 
BEPS, many states adopted uncoordinated fiscal fail-safes that linked tax treatment in the residence state to tax treatment at source. ${ }^{179}$ Worldwide taxation and CFC regimes can be viewed as unilateral fiscal fail-safes; they trigger additional tax at residence when there has been (in the residence state's view) insufficient tax at source. Recently, the United States proposed bilateral fiscal fail-safes in its model tax treaty. ${ }^{180}$ But it is easier for multinationals to avoid a particular state's fiscal fail-safe than it is to avoid the coordinated fiscal fail-safes of a large number of countries. The relative effectiveness of coordinated fiscal fail-safes compared to unilateral fiscal fail-safes may explain why, since the 1960s, the United States has advocated a kind of "mutually assured taxation" by campaigning for other states to adopt CFC regimes on the U.S. model. ${ }^{181}$

A key feature of fiscal fail-safes is that they facilitate coordination while neutralizing holdouts. The gains of BEPS were not distributed evenly, and neither were its costs. While the larger goal of BEPS was to reduce corporate tax avoidance and increase tax revenue for its participants, BEPS also created risks not only for tax havens, which stood to lose revenue, but also for relatively high-tax countries, such as the United States. The need to neutralize defection by tax havens is obvious, but the need to neutralize U.S. resistance to BEPS requires further explanation.

The United States broadly supported the BEPS Project, but it also had good reasons to be concerned about its outcomes. First, the United States was worried about its own companies. The world's largest multinational companies are disproportionately American. ${ }^{182}$ Thus, efforts to prevent corporate tax avoidance by multinationals could be expected to disproportionately impact U.S. companies operating abroad and potentially harm their competitiveness. Second, the United States was worried about losing real business activity. The BEPS slogan was to "align tax with value creation." If factors of production would constitute the measure of "value creation," then aligning tax with value creation would motivate companies to move productive factors out of high-tax states. The United States had more reason to be concerned about real factor movement than other countries because at the beginning of the BEPS Project it had one of the highest statutory corporate tax rates in the world. Third was a pure revenue concern. Because the United States had a worldwide tax system in which it relieved double tax by crediting other states' taxes, avoidance by U.S. companies of foreign taxes ultimately redounded to the U.S. fisc in the form of lesser claims to foreign tax credits. BEPS measures that succeeded in increasing U.S. companies' foreign tax burden therefore would, in time, hit the United States in the pocketbook. The unique position of the United States as a high-tax home to an outsize share of large multinationals engaged in

179 See, e.g., Richard Resch, The New German Unilateral Switch-Over and Subject-to-Tax Rule, 47 EUR. TAX'N 480 (2007) (describing switch-over and subject-to tax rules, which both function as what I would call unilateral fiscal fail-safes; they trigger special tax by the residence state when a source state has not sufficiently taxed).

180 See Allison Christians \& Alexander Ezenagu, Kill Switches in the New US Model Tax Treaty, 41 Brook. J. INT'L L. 1043 (2016) (discussing U.S. model treaty provisions that deny certain treaty benefits to income tax benefits from special tax regimes available in the partner state or when the partner state changes its tax law in certain specified ways after conclusion of the treaty).

${ }^{181}$ U.S. Department of the Treasury, Office of Tax Policy, The Deferral of Income Earned Through U.S. Controlled Foreign Corporations: A Policy Study, at 1-11 (2000) (describing history of U.S. regime from the 1960s).

${ }^{182}$ Kimberly A. Clausing, Does Tax Drive the Headquarters Locations of the World's Biggest Companies?, 25 Transnat'L Corp. 37, 44 (2018) (noting that the "United States has, by far, the most companies from the Global 2000," a list of the top 2,000 companies). 
aggressive tax planning therefore created special risks for the United States compared to its BEPS partners. ${ }^{183}$ Thus, BEPS participants rationally desired recommendations that could be effective even if the United States or tax havens did not implement them.

That fiscal fail-safes are effective for achieving full taxation or at curbing state defection is not enough to conclude that they are a good idea. The normative arguments for fiscal fail-safes resemble those against tax sparing. ${ }^{184}$ Fiscal fail-safes—which impose additional taxes where foreign tax was never due-are the inverse of tax sparing, which grants credits for foreign taxes never paid. ${ }^{185}$ Fiscal fail-safes may increase revenue, ${ }^{186}$ promote the perceived fairness of tax regimes (by discouraging tax breaks for multinationals or bespoke tax deals for particular companies), reduce rent-seeking activity, and reduce both paper profit shifting and real locational distortions. ${ }^{187}$ Against these virtues would be set the vices of fiscal fail-safes. Specifically, fiscal fail-safes impinge tax autonomy and inhibit tax competition by clawing back the benefit of low tax rates or tax holidays. Fiscal fail-safes thus may be criticized as paternalistic, and they may drive competition to other arenas, such as direct subsidies. ${ }^{188}$

Putting aside these normative considerations, conceptualizing familiar and longstanding unilateral anti-abuse rules as fiscal fail-safes reveals incremental acceptance of the full-tax norm. Moreover, the BEPS Project adds a new dimension by standardizing and coordinating fiscal fail-safes. ${ }^{189}$ In addition to being more effective at curbing abuse, coordinated fiscal fail-safes reduce and spread the risk that companies and investment will flee to other jurisdictions. Moreover, coordination reduces the risk that fiscal fail-safes could create new tax arbitrage opportunities. Finally, coordination may lower compliance costs and double-tax risks for taxpayers, thereby facilitating cross-border commerce. Consistent with this reasoning, the EU member states used EU-level legislation to adopt many of the BEPS recommendations-including fiscal fail-safes that were not minimum standards, such as anti-hybrid and CFC rules. ${ }^{190}$

${ }^{183}$ Bob Stack, the chief BEPS negotiator for the United States during the Obama administration, ruefully observed that every other country sought to gain revenue at the expense of the United States. He quipped, "it seemed like the question for consensus was, 'Should Bob pay for everyone's lunch?' And you'd all say, 'Well, of course." Conversations: Jeffrey Owens and Robert Stack, 87 TAX Notes InT'L 715, 717 (2017) [hereinafter Interview with Stack].

${ }^{184}$ States adopt tax sparing to ensure that their residents keep the benefits of tax holidays and other preferential regimes granted by source states. The sparing state pretends that its resident taxpayer paid tax at the source state's normal rate, and the sparing state grants the taxpayer credit accordingly. The United States has long opposed (and consistently refused to adopt) the practice of tax sparing. Kim Brooks, Tax Sparing: A Needed Incentive for Foreign Investment in Low-Income Countries or an Unnecessary Revenue Sacrifice?, 34 QuEEN's L.J. 537, $538-46$ (2009) (surveying arguments for and against tax sparing).

185 See, e.g., id.

${ }^{186}$ Resulting revenue could be retained in full by either state or shared between them.

${ }^{187}$ Fiscal fail-safes accomplish this as worldwide taxation does, by clawing back the tax advantages of moving.

188 The arguments against fiscal fail-safes therefore parallel the arguments for tax sparing. Cf. Brooks, supra note 184 , at 546-53 (surveying arguments and explanations for persistence of tax sparing)

${ }^{189}$ In addition to enabling states' to cooperate to reduce tax competition, fiscal fail-safes can be seen as a twostage game in which a subset of states (usually high-tax residence states) agrees on a fail-safe in stage 1, and then all states respond in stage 2 by aligning their systems with triggering threshold. For strategic analysis of recent reforms of the U.S. fiscal fail-safe known as GILTI, see Susan C. Morse, GILTI: The Co-operative Potential of a Unilateral Minimum Tax, 2019 Brit. Tax Rev. 512; G. Charles Beller, GILTI: "Made in America" for European Tax: Unilateral Measures and Cooperative Surplus in the International Tax Competition Game, 38 VA. TAX REV. 271 (2019).

${ }^{190}$ See, e.g., Council Directive 2016/1164 of 12 July 2016 laying down rules against tax avoidance practices that directly affect the functioning of the internal market, 2016 OJ (L 193) 1 [hereinafter ATAD I] (requiring states to adopt: (1) one of two versions of a CFC rule; (2) hybrids rules; (3) exit taxation; (4) interest deductibility limits; 


\section{Peer Review}

As in other areas of law, such as banking and tax-information exchange, state compliance with BEPS will be monitored with peer review. ${ }^{191}$ The key to peer review is the existence of clear and uniformly applicable standards. Now that the OECD and G20 states have agreed in principle to certain standards, the Inclusive Framework will flesh out the detailed requirements that states must meet to comply with those standards. ${ }^{192}$ In the peer-review process, multinational teams of tax administrators examine compliance according to fixed rubrics. Gradations of compliance allow nuanced distinctions among states as well as rewarding them for incremental implementation of the relevant standards. ${ }^{193}$ Peer-review processes are phased and iterative - a noncompliant country has opportunities to come into compliance, and the monitoring process provides clear direction to the reviewed state for how to comply and improve its rating. Phased reviews sort easy-to-meet standards before more demanding standards to promote trust among reviewed states and to increase the chances that states will cooperate in the next phase of review. The peer-review process also can be expected to generate positive externalities for enforcement and dispute resolution as tax administrators who work together on peer reviews build trust that they carry over into competent authority disputes or multilateral audits. ${ }^{194}$ In contrast with the OECD's earlier Harmful Tax Practices Project, all participating states, including powerful OECD states, are subject to the same standards. ${ }^{195}$ An underappreciated aspect of the process is that engaging the Inclusive Framework in developing peer-review standards gives non-OECD, nonG20 countries an opportunity for meaningful participation in the post-BEPS work.

Together, the various BEPS reforms - including the Multilateral Instrument and other bilateral treaty changes, coordinated unilateral measures including fiscal fail-safes, enhanced disclosure and transparency initiatives and peer-review monitoring-substantially increase countries' commitments to international tax cooperation.

\section{The Future of International Tax}

So far, this Article has argued that the impact of BEPS must be measured not only by its list of deliverables, but also by how, compared to prior practice, it changed participants, institutions, agenda, norms, and forms of international tax cooperation. This Part evaluates the normative desirability and durability of the BEPS changes, including its impact on revenue, inclusivity, and accountability; it also considers how BEPS may constrain state tax autonomy and entrench even poor policy choices. This Part also raises some conceptual objections to full

and (5) a general tax anti-abuse rule); Council Directive 2017/952 of 29 May 2017 Amending Directive 2016/1164 as Regards Hybrid Mismatches with Third Countries, 2017 OJ (L 144) 1 [hereinafter ATAD II] (expanding anti-hybrids rule to cover cases between the EU and non-EU member states).

${ }_{191}$ See generally Christians, supra note 1 (describing procedure and noting long history of this practice in tax); Grinberg, supra note 90 (explaining that BEPS borrowed techniques from international financial law).

192 See generally InClusive FrameWORK BRIEF, supra note 106.

193 See, e.g., OECD/G20, MAP PeEr Review Report, United States: Stage 1, at 9 (2017) [hereinafter MAP Peer Review of United States] (rating the United States "compliant" in some areas and "not fully compliant" in others).

${ }^{194}$ See Transfer Pricing Guidelines, supra note 15, at 422 (touting peer reviews of transfer-pricing practices as an opportunity to learn and disseminate best practices).

195 See, e.g., MAP PeEr Review of United States, supra note 193. 
taxation as a norm and argues that states' unwillingness to grapple with distributive issues created new risks of double taxation. The unaddressed distributive questions and the specter of reemergence of double taxation have triggered a new project at the OECD, known as BEPS 2.0 , to reconsider and update 1920 s-era tax-treaty rules, including the permanent establishment requirement. This Part concludes that because states lack shared views regarding how to efficiently and fairly divide entitlements to tax cross-border commerce, bargaining over national self-interests will likely determine the outcome of BEPS 2.0. However, loftier values of efficiency and justice and the more quotidian consideration of administrability will likely govern the formulation of the technical rules to implement the agreed outcome.

\section{A. Revenue}

It is too early to know the revenue effects of BEPS. ${ }^{196}$ We have never fully understood the size of profit shifting, particularly for countries for which good data is unavailable. ${ }^{197}$ For example, one recent paper argues that the method economists use to measure profit shifting results in systematic overestimation. ${ }^{198}$ That claim has been disputed. ${ }^{199}$ Notwithstanding data gaps, because nearly all the BEPS recommendations were designed to prevent corporate tax avoidance, it seems reasonable to assume that the net outcome of BEPS will be to raise revenue. One of the BEPS recommendations will generate more reliable data for measuring profit shifting. ${ }^{200}$

\section{B. Inclusivity}

Among the things BEPS did not change was the significant participation in international tax by the business community. Post-BEPS, however, more stakeholders participate in international tax policymaking than ever before. Still, it is too soon to declare victory for pluralism. First, commentators disagree over the value of participation by NGOs. Shu-yi Oei and Diane Ring argue that NGOs wield substantial power untempered by politically accountability. ${ }^{201}$ On the other hand, participation by these groups makes international tax law more salient, converting it from a seldom-traveled backwater, navigated only by those with technical tax training, to a more mainstream process.

Second, it is too soon to evaluate the impact of the Inclusive Framework. Although all Inclusive Framework members ostensibly participate in BEPS implementation questions on an "equal footing," it remains to be seen how much influence smaller and poorer countries

${ }^{196}$ For example, the OECD has not yet released empirical findings to the public.

197 See, e.g., ADDRESSING BEPS, supra note 25, at 61-71 (discussing data problems); Kim Clausing, The Effect of Profit Shifting on the Corporate Tax Base in the United States and Beyond, 69 NAT'L TAX J. 905 (2016) (estimating that profit shifting reduced U.S. corporate tax revenues by between a quarter and a third in 2012).

${ }^{198}$ Jennifer Blouin \& Leslie Robinson, Double Counting Accounting: How Much Profit of Multinational Enterprises Is Really in Tax Havens? (forthcoming).

${ }^{199}$ Kim Clausing, Profit Shifting Before and After TCJA (forthcoming) (in part correcting estimates for the effect Blouin and Robinson identified).

${ }^{200}$ See OECD, Measuring and Monitoring BEPS, Action 11 Final Report (2015) (calling for collection and sharing of data).

201 Oei \& Ring, supra note 79, 589 (warning that "agendas of various actors may inadvertently influence or consciously manipulate broader government priorities”). 
will have on important agenda-setting or policy decisions. ${ }^{202}$ Commentators have argued that the participation of non-OECD, non-G20 countries in the Inclusive Framework represents an attempt by ambitious OECD bureaucrats to increase their own influence and to ward off competition from the UN. ${ }^{203}$ Certainly, the interests of Inclusive Framework members are divided, and a desire by OECD members to retain control of the agenda and content of the international tax regime suggests that these states-perhaps joined by the rest of the G20will find ways to exclude other countries, for example by making important post-BEPS decisions outside of the Inclusive Framework.

Relegating the Inclusive Framework primarily to peer review of implementation of BEPS 1.0 minimum standards would reinforce developed countries' control over international tax policy, while maintaining the appearance of inclusivity. Even if developing countries formally had an equal voice at the OECD in agenda-setting and policy decisions, they have vastly less technical capacity than the OECD and G20 states. ${ }^{204}$ In tax, as in other areas, control over the technical rules often equates to control over substantive policy. The most significant impact of BEPS in terms of inclusivity, therefore, may have been to add G20 countries that are not members of the OECD to the formal decision-making process. ${ }^{205}$

\section{Accountability}

Democratic accountability concerns regarding international tax policymaking-such as claims that national representatives to the OECD are unelected bureaucrats and that OECD members deliberate in secret-predate BEPS. ${ }^{206}$ By expanding the agenda of international tax, BEPS exacerbates these concerns. ${ }^{207}$ Those uncomfortable with the normative implications of this descriptive claim could advocate for increasing the accountability of the OECD by, for example, making its deliberations and budget public. ${ }^{208}$

${ }^{202}$ Cf. Avi-Yonah \& Xu, supra note 1, at 211 (“[a]lthough over sixty countries were directly involved in the process of the BEPS project, they account for less than one-third of the 193 UN members").

203 Christians, supra note 1 , at 1602

${ }^{204}$ InClusive FrameWORK BRIEF, supra note 106, at 10.

${ }^{205}$ The G20 accounts for the vast majority of all international commerce. See, e.g., G20, G20 Participants, supra note 103 ("G20 members account for 85 per cent of the world economy, 75 per cent of global trade, and twothirds of the world's population, including more than half of the world's poor.").

${ }^{206}$ Paul B. Stephan, Accountability and International Lawmaking: Rules, Rents and Legitimacy, 17 Nw. J. INT'L L. \& Bus. 681 (1997) (exploring accountability and how to increase it in international law); Pierre-Hugues Verdier, Transnational Regulatory Networks and Their Limits, 34 YALE J. INT'L L. 113, 170 (2009) (identifying a tension between the effectiveness and accountability of transnational networks).

${ }^{207}$ Implementation of OECD recommendations via EU legislation raises new accountability concerns because the EU tax legislative process does not involve meaningful democratic participation; it thereby further reduces democratic checks on international tax policymaking.

${ }^{208}$ Contrarily, some may argue that because tax policy is so complicated, it likely always will be made by technocrats in processes that lack robust democratic accountability. On this account, we might conclude that it does not matter whether domestic technocrats or international groups of technocrats make tax policy.

The text asserts only that the OECD lacks democratic accountability compared to typical domestic tax lawmaking procedures. But the OECD derives legitimacy in other ways, including through member-state voting and budget control, limited public notice-and-comment practices, and bureaucrats' concerns about their own reputations with their peers, which may lead them to assert reasoned arguments, rather than arguments grounded solely in the relative power of the state they represent. Public protests over Starbucks revealed that international tax policy can also at least occasionally spark significant discipline from voters. 


\section{Constrained Policy Outcomes}

As tax policy becomes more international, it may become more constrained, homogenous, and entrenched. Indeed, tying domestic hands is part of the point of international law. With fiscal fail-safes, this effect is intentional; states often implement them with the goal of influencing other states' rules. Other types of cooperation involve unintentional restraints. For example, in a phenomenon dubbed "the Luxembourg effect" in a nod to the seat of the Court of Justice of the European Union (CJEU), Lilian Faulhaber observed that EU law may limit international tax reform efforts. ${ }^{209}$ When negotiating at the OECD, EU member states can only agree to reforms that are compatible with their obligations under EU law. Thus, on issues where a harmonized approach is needed or desirable, EU law effectively limits the options of non-EU members.

But that influence goes both ways - just as EU law sets limits on what can be accomplished at the OECD, OECD standards diffuse into EU law, generating a "Paris effect." ${ }^{210}$ For example, the EU Commission modified its own anti-hybrids proposal to match the one recommended as part of BEPS. ${ }^{211}$ Likewise, the CJEU has repeatedly deferred to OECD standards, ${ }^{212}$ even though not all the EU member states are also OECD members. ${ }^{213}$ And in its state-aid investigations, the EU Commission relied in part on the OECD Transfer Pricing Guidelines to determine whether member states made illegal sweetheart tax deals with multinationals. ${ }^{214}$ Nor is the Paris effect limited to the EU. OECD standards diffuse into the laws of the many non-OECD states that rely on the OECD Model and other OECD guidance.

As the number and interests of countries making international tax policy expands, consensus will be harder to reach, which may result in compromise positions that then become entrenched. OECD policies became entrenched even in the pre-BEPS era when fewer states were involved in multilateral standard setting. For example, the widespread acceptance of the OECD Transfer Pricing Guidelines undoubtedly entrenched the arm's-length standard. ${ }^{215}$ The recent outcry over the possibility that the European Commission might introduce an arm's-length standard that differed from the OECD arm's-length standard, and intervention

${ }^{209}$ Lilian V. Faulhaber, The Luxembourg Effect: Patent Boxes and the Limits of International Cooperation, 101 Minn. L. Rev. 1641 (2017) (referencing the work of Anu Bradford). See, e.g., Anu Bradford, The Brussels Effect, 107 Nw. U. L. REv. 1 (2015) (arguing that the EU influences world standards and regulations).

${ }^{210}$ See generally Eur. Comm'n, Proposal for a Council Directive Laying Down Rules Against Tax Avoidance Practices that Directly Affect the Functioning of the Internal Market, COM(2016) 26 final, at 5 (Jan. 28, 2016) (describing efforts to keep EU law consistent with BEPS outcomes).

211 See PARADA, supra note 169, at 178 (arguing that the rule ultimately adopted in the EU "represents a surrender to the political pressure at the OECD").

212 See, e.g., Case C-279/93, Finanzamt Köln-Altstadt v. Schumacker, ECLI:EU:C:1995:31, Judgment, para. 32 (Eur. Ct. Just. Feb. 14, 1995) (deferring to OECD standards).

213 Most of the twenty-seven EU member states are also OECD members, but Bulgaria, Croatia, Cyprus, Malta, and Romania are not.

${ }^{214}$ Mason, Subsidies, supra note 47, at 519, n. 179.

${ }^{215}$ Mary Bennett, Head of the Tax Treaty, Transfer Pricing \& Financial Transactions Division at the OECD, Panel Statements, Made at the International Tax Conference on the Common Consolidated Corporate Tax Base, Berlin (May 15-16, 2007), in A Common Consolidated Corporate Tax Base for Europe 139 (Wolfgang Schön, Ulrich Schreiber \& Christoph Spengel eds., 2008) (noting that due to the "widespread acceptance across the globe" of the arm's-length principle, "[a] move away from [that] principle in an important and sophisticated region ... may have unpredictable consequences"). 
by the United States to foreclose that possibility, highlights the constraining effect of internationalizing tax. ${ }^{216}$ Entrenchment of international standards results from the sunk costs of developing and building consensus around standards. It also arises from clientele effectsonce companies and tax practitioners learn how to exploit a standard, they advocate against its reform. ${ }^{217}$ Entrenchment can be deepened by tying other benefits to agreed standards. For example, countries must commit to the arm's-length standard as a condition to OECD membership, entrenching it as part of what might be called the OECD acquis. ${ }^{218}$ With BEPS, the OECD acquis expanded to nonmember states; to join the Inclusive Framework, states "must commit to the comprehensive BEPS package."219

That international regimes interact is not new. But as regimes proliferate, so do the crossconstraints they impose. As international obligations grow, they will continue to close off viable paths for reform and innovation. For example, the strictures of tax treaties may stand in the way of domestic and multilateral tax reform. ${ }^{220}$ To the extent that such reforms are normatively desirable, the blocking effect is unfortunate. On the other hand, tax treaties also may prevent protectionist or unwise national taxes.

\section{E. The Indeterminism of Full Taxation}

While intuitively attractive, when not paired with a clear distributive rule that dictates which state or states should tax cross-border income, the concepts of full taxation and double taxation are indeterminate-there is no way to specify the tax base or rate that would satisfy them. ${ }^{221}$ Although commentators using terms like "double non-taxation" may have in mind an approximate tax base (perhaps financial accounting income with adjustments for tax) and an approximate tax rate (something like the OECD average rate), such vague notions are too imprecise to generate clear policy prescriptions. Because tax systems differ across jurisdictions, determining how much income a company has, and the rate at which that income should be taxed, requires a rule for deciding which state's rules for calculating income and tax rates will

216 See Mason, supra note 95 (discussing the controversy).

217 See, e.g., Rosenzweig, supra note 66 (discussing failed efforts to repeal check the box). The revolving door between government and practice also entrenches such standards by allowing former government officials to cash in on their knowledge of government's interpretations and enforcement practices.

${ }^{218}$ In EU law, the acquis or acquis communautaire refers to "the body of common rights and obligations that are binding on all EU countries, as EU Members.” EU, Acquis, at https://eur-lex.europa.eu/summary/glossary/acquis. html. EU candidate countries must reform domestic law to bring it in line with the EU acquis before acceding to membership in the EU. Id. The "OECD acquis" would include the large set of tax standards formulated by the OECD, including the OECD Model Treaty and Commentary, and the Transfer Pricing Guidelines.

${ }^{219}$ InClusive Framework BRIEF, supra note 106, at 11. The BEPS package includes the four minimum standards that all the Inclusive Framework states commit to implement. Id.

220 See Rebecca Kysar, Unraveling the Tax Treaty, 104 MinN. L. Rev. 1755 (2020) (arguing that the new U.S. base-erosion anti-abuse tax (BEAT) may violate U.S. tax treaties).

221 The distributive rule of full taxation is vague; it says only that taxes should be allocated to where companies have real factors of production (or, in recent parlance, where value is created). As conceived by Avi-Yonah, however, the single-tax principle includes: (1) a distributive rule based on the 1920s bargain that instantiated the benefits principle and fully assigns income-active to source, passive to residence, and any untaxed income effectively to residence; (2) a tax base, defined by the source state for active income and by the residence state for passive and residual income; and (3) upper and lower tax-rate bounds set by the residence and source states. Avi-Yonah, supra note 136, 517-23. That Avi-Yonah's single-tax principle includes a distributive rule lends it false precision. As AviYonah readily recognizes, the benefits principle does not "provide a clear answer to the question of how to divide the corporate income tax base among the various jurisdictions providing benefits." Id. at 522 . Thus, the single-tax principle is also indeterminate. 
apply. Thus, states first must decide how to split a multinational's income among themselves before they can determine whether the multinational has been subject to too much tax ("double tax") or too little tax (less than "full tax" or "double nontax"). Without clear consensus rules to allocate tax entitlements, a generalized norm of full taxation can lead to double taxation in exactly the same way that a generalized norm of no-double taxation can lead to nontaxation. ${ }^{222}$

Perhaps no issue better demonstrates the problems that arise from lack of consensus over allocation than recent digital tax debates. Even though the BEPS participating states identified misallocation of income from "the digital economy," as a serious issue at the outset of the Project, ${ }^{223}$ the United States, keenly aware of its own interests, convinced other states that the digital economy could not be "ring-fenced" or cleaved off from the rest of the economy and taxed separately. ${ }^{224}$ In addition to sidelining discussions about the digital economy, negotiators also did not fundamentally rethink the 1920s-era tax-treaty distributive framework that is based on a source-and-residence paradigm. ${ }^{25}$ But failure of that preexisting framework to keep pace with changes in the global economy, and its consequent inability to generate acceptable tax outcomes for source countries, has resulted in states' declining fidelity to it.

The idea behind BEPS was to end nontaxation of corporate income, and instead to substitute full taxation. Because states did not want to tackle the distributive question, however, they either arbitrarily allocated the new revenue that arose from closing tax gaps, or they relied on preexisting source-and-residence rules. ${ }^{226}$ Consider the anti-hybrid rules that close tax gaps that arise from different states' definitions of debt and equity. The primary anti-hybrid rule fills the gap by requiring the payer state to deny an interest deduction, thus allocating revenue to the payer state. If the payer state does not adopt the anti-hybrid rule, then the defensive rule requires the recipient's state to include the payment, thus allocating revenue to the recipient state. What BEPS did not do, however, was resolve which of the two states was more entitled to the revenue and why, nor did the BEPS states determine whether some third state might have a legitimate claim to the revenue.

Similarly, under the BEPS recommendation for CFC regimes, income that had not been subject to enough ${ }^{227}$ tax at source would be subject to additional tax at residence in order to

\footnotetext{
${ }^{222}$ Without a clear distributive rule, if they both follow a non-double-tax norm, two states with claims to tax an item of income could both forebear under the assumption that the other is more suited to tax, resulting in nontaxation. Likewise, without a clear distributive rule, multiple states following a full-tax norm could seek to tax the same item of income, resulting in double tax.

${ }^{223}$ BEPS ACTION PLAN, supra note 85, at 14-15 (noting companies could "have a significant digital presence in the economy of another country without being liable to taxation due to the lack of nexus under current international rules").

2242016 BEPS EXPLANATORY STATEMENT, supra note 97, at 13.

225 BEPS Action Plan, supra note 85, at 11 ("While actions to address BEPS will restore both source and residence taxation in a number of cases where cross-border income would otherwise go untaxed or would be taxed at very low rates, these actions are not directly aimed at changing the existing international standards on the allocation of taxing rights on cross-border income.").

226 See Brauner, supra note 1, at 997 ("The OECD decided, without any explanation or analysis, the consequences of these choices. . . . The solutions . . . are merely technical.”)

${ }^{227}$ CFC regimes include an implicit distributive rule that lodges residual income with the residence state. Thus, in this case, "enough" would be evaluated from the residence state's perspective. In some versions, CFC rules provide for additional residence tax when the source tax rate was not high enough as a percentage of the residence-state's rate. CFC rules therefore go beyond full taxation (all income taxed in states where there are factors, according to the factor states' income-calculation rules and tax rates) to also achieving worldwide taxation (all
} 
achieve full taxation. ${ }^{228}$ By clawing back the benefit of low-source taxes, CFC rules encourage source states to tax more. Like the anti-hybrid rules, CFC and other types of minimum-tax rules seem more concerned with whether companies pay tax than where they pay tax. Such BEPS recommendations reflect a new commitment to full taxation, but they also reflect ambivalence or reluctance to confront the underlying distributive issue. This ambivalence only went so far, however. Although income typically taxed at source might be taxed at residence, and vice versa, ${ }^{229}$ states did not use the BEPS Project to fundamentally rethink which states should be entitled to the labels "source" and "residence." Likewise, although the BEPS countries purported to align taxation with value creation, because they never adequately defined what that alignment entailed, advocates saw in it what they wanted to see. ${ }^{230}$

The concept of full taxation says that income should not go untaxed, but it does not specify where it should be taxed — whether at source, residence, or in some third state that lacks a tax entitlement under current rules. Having accepted full taxation as a norm, countries now face a new challenge: to avert a kind of free-for-all in which many states try to fill the same tax void. Consider the following examples.

First, Leopoldo Parada has extensively explored the double taxation that may arise from application of the BEPS anti-hybrid rules. ${ }^{231}$ Second, to the extent that country-by-country reports reveal untaxed income, they may invite taxation by multiple states according to different theories of "value creation." ${ }^{232}$ Third, double tax may emerge as a result of disclosure of previously secret tax rulings. The European Commission's state-aid investigations attest to the possibility that tax-ruling disclosure may lead to double-tax, or at least to conflicting claims to tax income. Analysis by the Commission of member state tax rulings revealed that U.S. multinationals were shifting their profits out of EU states and into tax havens or

income, defined according to the residence state's income-calculation rules, taxed at a minimum of the residence state's rate). A worldwide tax system is fully specified, under it, there would be a clear answer to whether the taxpayer had been subject to full tax or double tax. A formula apportionment system with a common base and formula is likewise fully specified when combined with each state's rate.

The minimum tax proposed as part of BEPS 2.0 pairs a residence-based inclusion rule with an undertaxed payment rule that triggers source tax when residence taxation will be insufficient. This approach closely resembles the primary and defensive rules in the anti-hybrid rules and can be similarly criticized for prizing full taxation ungrounded by a distributive theory.

228 OECD, Designing Effective Controlled Foreign Company Rules: Action 3 (2015).

${ }^{229}$ See H. David Rosenbloom \& Joseph P. Brothers, Reflections on the Intersection of U.S. Tax Treaty Policy, U.S. Tax Reform, and BEPS, 78 TAX Notes INT'L 759, 764 (May 25, 2015) (arguing that many of the BEPS reforms, including "actions addressed to the digital economy, base erosion, neutralizing the effects of hybrid mismatch arrangements, preventing the artificial avoidance of PE status," transfer-pricing reforms, and disclosure rules all point to greater source taxation as compared to before BEPS).

${ }^{230}$ Cooper, supra note 1, at 147 ("everyone could read into it whatever they wanted it to mean").

${ }^{231}$ Parada traces these problems to what this Article refers to as the full-taxation approach. See Parada, supra note 120, at 972, 981 (criticizing the anti-hybrid rules' "consequentialist approach" that demands tax "no matter where"); PARADA, supra note 169, at 51 (arguing that "double nontaxation" is not necessarily cause for concern). See also Brauner, supra note 1, at 1035 (criticizing the anti-hybrid rules because " $t$ ] here is no principle-based reason, except for perceived administrative convenience, to choose these and not other countries" to tax). Graeme Cooper aims his criticism more broadly, arguing that the BEPS goal to combat "double non-taxation" is "largely value-free. It laments an outcome but does not apportion blame." Cooper, supra note 1, at 148 .

232 See Brauner, supra note 1, at 1032 (noting concerns that states might use the reports to assess tax according to formulary apportionment, rather than the consensus arm's-length standard). 
to nowhere. ${ }^{233}$ But the Commission's response prized full taxation over clear thinking about where income should be taxed. ${ }^{234}$ For example, as a result of its investigation of Ireland for issuing sweetheart rulings to Apple that the Commission determined aided Apple in its stateless income planning, the Commission ordered Apple to pay $\$ 14$ billion in taxes to Ireland. Even though most people might agree that a substantial portion of Apple's income should not be stateless, that it should be taxed by Ireland is far from obvious. The result of the Commission's state aid investigation seems not only arbitrary, but generative of serious disputes with other countries — including the United States and other EU states - that would seem to have superior claims to Ireland to tax Apple's stateless income. ${ }^{235}$ Assigning Apple's stateless income to Ireland ensured full taxation, but not in a way that genuinely reflected where "value was created."

In sum, despite academic commentary that justifiably criticized BEPS for failing to squarely tackle the allocation question, ${ }^{236}$ perhaps the most important implication of BEPS was that by building consensus for full taxation, it heated up discussions about which state should step in to fill tax voids. As the next section explains, as states scramble to fill tax vacuums, they generate renewed risks of double taxation, prevention of which may drive further multilateral cooperation.

\section{F. Reallocation: BEPS 2.0}

After a century of uneasy postponements, governments are now confronting the allocation question. The 137 states in the BEPS Inclusive Framework have set the end of 2020 as the deadline for devising "a fairer and more stable" allocation of tax entitlements among states. ${ }^{237}$ These BEPS 2.0 negotiations involve three major issues: (1) how to redefine the permanent establishment threshold for the modern economy; (2) how to attribute income to the permanent establishment, as redefined; and (3) a proposal, not discussed here, to adopt minimum tax rates as a fiscal fail-safe that would also help curb tax competition. ${ }^{238}$ Different proposals

\footnotetext{
233 See, e.g., Mason, supra note 95 (detailing the Apple state-aid investigation). Public comments by thenCommissioner of Competition Margrethe Vestager suggested that the Commission was guided by a full-taxation norm in its investigations. See Speech by Vestager, TAXE 2 Committee, at 2 (Apr. 4, 2016) (noting about transferpricing rulings that some "look at just one side of a transaction. They decide on an appropriate profit for the activities of just one company of a group. As for the profit that remains, it might be taxed somewhere else-or it might not be taxed at all. This creates a potential for loopholes.").

234 See, e.g., id. (critically analyzing the Commission's state-aid cases).

${ }^{235}$ As a result of the Commission's ruling, Ireland ends up with a large share of Apple's profit from all of Europe, the Middle East, India, and Africa, and Asia-Pacific regions. See id. Interestingly, perhaps uncomfortable with the result of its own investigation - that a very large portion of Apple's income should be taxed by Ireland-the Commission suggested that not only other EU member states, but also the United States, should make backtax claims against Apple, and that doing so would reduce the tax Apple owed to Ireland. See id. When not grounded by a clear allocation rule, notions of "full taxation" lend themselves to this kind of indeterminism about which state should tax.

236 See generally Herzfeld, supra note 1, at 7; Brauner, supra note 1, at 1021; Cooper, supra note 1, at 174.

237 OeCD, Programme of Work to Develop a Consensus Solution to the Tax Challenges Arising from the Digitalisation of the Economy 7 (2019) [hereinafter OECD Work Program] (describing the timeline as "extremely ambitious").

${ }^{238}$ See generally id. This proposal is based loosely on the 2017 reforms to U.S. law, but is more comprehensive. For more on U.S. law, see references cited in note 189 supra. Although the OECD minimum-tax proposal is very interesting and represents the most ambitious attempt by states so far to adopt coordinated fiscal fail-safes, it is beyond the scope of this Article.
} 
would modify the permanent-establishment threshold in various ways (for example, by introducing the concept of digital presence) and allocate more income to the states of users and consumers (collectively, market states). States have also floated new methods to attribute profits to the permanent establishment; these methods would depart from the sacred arm's-length standard by, for example, relying on formulas.

Although we will not know the results of BEPS 2.0 for some time, this section considers factors that may influence potential outcomes, and it concludes that national self-interest will be the most important driver of any resolution of the allocation question, ${ }^{239}$ but efficiency, fairness, and administrability concerns will likely shape the formulation of any resulting rules.

\section{Absence of Agreed Norms}

Reformers insist that states must "align taxation with where value is created." 240 Such assertions represent claims that the distributive impact of the current international tax regime-the allocation of tax entitlements-must change. But there is no ready answer to what distributive scheme should replace it. In the absence of shared conceptions of efficiency or distributive justice, policymakers will seek to promote national self-interest.

At the inception of tax treaties in the 1920s, policymakers asked economists how countries should tax cross-border income; then, as now, economists did not agree on a single answer. ${ }^{241}$ Economics does not directly answer the question of where income arises. ${ }^{242}$ That economics cannot answer the where question does not mean that economics cannot tell us whether some distributions are more efficient than others. But appeals to efficiency only get us so far. Neither economists nor policymakers agree about which rules generate the most efficient outcome or about whose welfare should be maximized. ${ }^{243}$ Nor have clear prescriptions emerged from empirical study. ${ }^{244}$

That national welfare considerations generate different policy prescriptions for different states seems obvious, but even pursuit of global welfare generates multiple incompatible policy

${ }^{239}$ But see Allison Christians, Sovereignty, Taxation and Social Contract, 18 MinN. J. INT'L L. 99 (2009) (otherregarding views ought to inform international tax under an implied global social welfare contract).

2402018 BEPS Progress REPORT, supra note 112, at 5 ("value creation"); BEPS ACTION Plan, supra note 85, at 11 (BEPS aims to "better align rights to tax with economic activity").

${ }^{241}$ Many have written about the history of tax treaties. See, e.g., Graetz \& O’Hear, supra note 12, Reuven S. AviYonah, The Structure of International Taxation: A Proposal for Simplification, 74 Tex. L. Rev. 1301 (1996); JOGARAJAN, supra note 12.

242 See Hugh J. Ault \& David F. Bradford, Taxing International Income: An Analysis of the U.S. System and Its Economic Premises, in Taxation in the Global Economy 11, at 31 (Assaf Razin \& Joel Slemrod eds., 1990) (remarking that, from an economics perspective, income has "no natural locational aspect").

243 See generally Michael J. Graetz, Taxing International Income: Inadequate Principles, Outdated Concepts, and Unsatisfactory Policies, 54 TAX L. REV. 261 (2001) (arguing that although policymakers assume and act as if the goal of U.S. international tax policy were global efficiency, the United States should pursue national welfare); Daniel Shaviro, Why Worldwide Welfare as a Normative Standard in U.S. Tax Policy?, 60 Tax L. REv. 155 (2007) (arguing that worldwide welfare as a global norm enhances national welfare by promoting cooperation).

244 See Harry Grubert \& Rosanne Altshuler, Corporate Taxes in the World Economy: Reforming the Taxation of Cross-Border Income, in Fundamental TAX Reform: Issues, CHOICES AND IMPLICATIONS 319 (John W. Diamond \& George R. Zodrow eds., 2008) (arguing that the welfare effects of the leading neutrality benchmarks are presently indeterminate and theoretical discussions of such welfare effects rely on very simple models); Mitchell A. Kane, Considering "Reconsidering the Taxation of Foreign Income," 62 TAX L. REV. 299, 310 (2009) ("nobody has yet undertaken any type of empirical work that could offer some indication of the relative magnitude of efficiency losses from ownership versus locations distortions produced by suboptimal international tax policy"). 
prescriptions. ${ }^{245}$ That different states may seek to maximize along different margins is wellknown. It is enough to observe that state representatives do not agree, and are not likely to agree, about how to use their international tax laws to achieve efficiency goals. Contrast the lack of consensus in income taxation with the consensus on the goals of trade agreements. Widely accepted, the theory of comparative advantage guides trade policy to ostensibly correct results - fewer and fewer tariffs, freer and freer trade. In most cases, the ideal tariff rate is zero. ${ }^{246}$ But income tax rates cannot be zero because states need revenue to fund public goods and to maintain social programs. If states are to ensure full tax while avoiding double tax, they must coordinate on the question of distribution - they must decide which state taxes which income. This does not mean that efficiency concerns have no place in the current allocation debate. But they are inconclusive on the most important question - namely, who gets what?

As with economic efficiency, there is also a lack of consensus on how to fairly allocate tax entitlements among states. Policymakers broadly adhere to the benefits principle, but that principle does not generate clear guidelines regarding the magnitude of each state's tax entitlement. Wolfgang Schön's trenchant observation about the concept of value creation-that it only tells us that income should not be allocated to tax havens ${ }^{247}$ - applies equally to the benefits principle. Although the benefits principle would largely reject allocation of tax entitlement to states where companies have no productive factors, it generates no clear guidelines regarding what proportions of income should be allocated to states with real factors of production (however generously defined). ${ }^{248}$

Nor do concerns about interpersonal equity typically drive international tax negotiations. ${ }^{249}$ Policymakers commonly phrase allocation questions in terms of efficiency,

\footnotetext{
${ }^{245}$ Ault \& Bradford, supra note 242, at 27 ("the tax treatment of international income flows reflects a variety of policy objectives, so it is difficult to ... state the optimizing problem to which the rules are the solution"); Harry Grubert, Tax Credits, Source Rules, Trade, and Electronic Commerce: Behavioral Margins and the Design of International Tax Systems, 58 TAX L. REV. 149, 153-54 (2005) (listing twelve different margins that international tax rules may distort). Id. (advocating that each policy should be evaluated according the relevant margin, rather than regarding any single policy choice "as a complex, second-best problem in which distortions along all margins must be considered”); Rosanne Altshuler, Recent Developments in the Debate on Deferral, 20 TAX NOTES INT'L 1579 (2000) (explaining the different prescriptions of the three leading international tax efficiency benchmarks, locational neutrality, savings neutrality, and competitive neutrality). See also Mason \& Knoll, supra note 120, at 103372 (discussing the leading benchmarks in terms of taxes on income from labor, and noting that the benchmarks have different implications for international tax rules); Ruth Mason, Tax Discrimination and Capital Neutrality, 2 WORLD TAX J. 126 (2010) (discussing incompatibilities in the policy prescriptions of the various benchmarks).

${ }^{246}$ Although policymakers have come to question both the welfare costs of free trade and the precise content of trade agreements, the underlying theory of comparative advantage enjoys widespread support. For a nuanced, rather than celebratory, account of free-trade agreements, see DANi RoDrik, STRAIGHT TALK ON TRADE: IDEAS FOR A SANE WORLD ECONOMY (2017).

${ }^{247}$ IFA/OECD Plenary Session, Int'l Fiscal Org. Annual Congress, London (Sept. 11, 2019) (remarks of Wolfgang Schön).

${ }^{248}$ For example, the current digital tax debate involves a dispute between users' states and technology companies' headquarters states about whether the presence in a jurisdiction of users themselves (or their data) generates a cognizable tax claim by the user's state. Even if states agreed it that it does, resolving the revenue division according to the benefits theory presumably would require estimating the benefits conferred to the multinationals by the users' states in comparison to the benefits conferred to the multinationals by the other states. The benefits theory therefore performs better at identifying the set of states that ought to be entitled to tax than it does at identifying the proportions that each state's entitlement should bear to the others' or which "classifications" of income should be taxed by which countries. Allocation based on factor apportionment would face the identical problem of indeterminacy.

${ }^{249}$ As Tsilly Dagan has observed, "cooperative efforts in the international tax arena rarely consider global justice." DaGAN, supra note 63, at 185-89 (discussing divergent philosophical views). See also Irene Burgers \& Irma
} 
enforcement, and legal jurisdiction; distributive justice concerns are pushed down to the national level where they can be resolved through democratic processes. ${ }^{250}$ Cooperative efforts, such as BEPS, that ensure that corporations pay their taxes can be seen as shoring up states' ability to effectuate domestic conceptions of justice, but they do so without developing an international conception of distributive justice. ${ }^{251}$

Commentators have offered many theories for how to divide income between source and residence, and for how to divide tax entitlements among states that may claim to be a source of a multinational company's income. Although splitting seems intuitively attractive, particularly if a company's productive factors — such as payroll, property, and sales - are present in more than one state, any particular split is hard to justify as a theoretical matter. Indeed, many current rules lack a convincing theoretical foundation-they represent arbitrary compromises. ${ }^{252}$

Moreover, source and residence tax represent only the two most familiar bases for tax. The academy has functioned as a kind of Pandora's box for corporate-tax allocation theories; credible arguments — arguments that rely on economic theory, conceptions of distributive justice, and pragmaticism - support not only taxation at source ${ }^{253}$ and residence, ${ }^{254}$ but also by the company's shareholders' state(s), ${ }^{255}$ its customers' states, ${ }^{256}$ the state where its products or services are used, ${ }^{257}$ and taxation according to various formulas that would take into account the presence in particular jurisdictions of the company's factors of production. ${ }^{258}$

Mosquera, Corporate Taxation and BEPS: A Fair Slice For Developing Countries?, 10 Erasmus L. Rev. 29 (2017) (giving reasons why conceptions of fairness may differ between developed and developing countries). Arguments about interpersonal equity may take the form of discussions as to which rules would best facilitate the resident state's application of domestic conceptions of ability to pay. For example, in the 1920s, some argued that residence states should tax worldwide income to effectuate ability-to-pay principles. See Graetz \& O'Hear, supra note 12, at 1035. This argument still holds sway, although ability-to-pay values also can be effectuated at source, as long as source states have access to reliable information concerning worldwide income.

250 See Nancy H. Kaufman, Fairness and the Taxation of International Income, 29 LAw \& POL'y InT'L Bus. 145 (1998) (distinguishing inter-individual equity from inter-nation equity); Ilan Benshalom, How to Redistribute? A Critical Examination of Mechanisms to Promote Global Wealth Redistribution, 64 U. ToronTo L.J. 317 (2014) (arguing that tax allocation rules can be used to redistribute global wealth).

251 But see DAGAN, supra note 63, at 203-06 (arguing that to make cooperation itself just, cooperation must improve the welfare of the least-well-off constituents of the cooperating states. Thus if cooperation will, for example, drive productive factors out of developing countries or increase the tax capacity of corrupt governments that do not use the revenue increase for redistribution, the cooperation may be unjust).

${ }^{252}$ For several categories of income, the OECD Model provides a maximum source-state withholding rate. See, e.g., OECD Model, supra note 6, Art. 11 (providing 10\% withholding on interest).

253 See generally Avi-Yonah, supra note 62 (advocating source tax).

${ }^{254}$ Graetz \& O'Hear, supra note 12, at 1035 (describing Edwin Seligman's advocacy for residence tax on the "economic allegiance" theory); See e.g., Robert A. Green, The Future of Source-Based Taxation of the Income of Multinational Enterprises, 79 CORNELL L. REV. 18 (1993) (advocating residence tax on ability-to-pay grounds).

${ }^{255}$ Eric Toder \& Alan D. Viard, A Proposal to Reform the Taxation of Corporate Income, TAX POL'y CTR.

256 See, e.g., Alan Auerbach, Michael P. Devereux, Michael Keen \& John Vella, Destination-Based Cash Flow Taxation (Oxford Univ. Centre for Bus. Tax'n WP 17/01, 2017).

257 Wei Cui, The Digital Services Tax: A Conceptual Defense (forthcoming) (recommending taxation of digital companies in their users' states).

${ }^{258}$ Reuven S. Avi-Yonah, Kimberly A. Clausing \& Michael C. Durst, Allocating Business Profits for Tax Purposes: A Proposal to Adopt a Formulary Profit Split, 9 FLA. TAX REV. 497 (2009) (proposing formulary apportionment); Orly Mazur, Transfer Pricing Challenges in the Cloud, 57 B.C. L. Rev. 643 (2016) (same). See also Proposal for a Council Directive on a Common Consolidated Corporate Tax Base (CCCTB), COM(2011) 121/4 (Mar. 15, 2011) (legislative proposal for formulary apportionment for the EU); Sol Picciotto, Taxing Multinational Enterprises as Unitary Entities, 82 TAX NOTES 895 (2016). 
Nor is the problem of dividing tax entitlements new. As far back as 1917, shortly before the emergence of our current international tax regime, T.S. Adams formulated the problem this way:

Here is a corporation whose owners live in jurisdiction A, whose factory is in jurisdiction $\mathrm{B}$, whose main offices are in jurisdiction $\mathrm{C}$, and whose principal sales department is in jurisdiction D. It needs no discussion to prove that each of these jurisdictions will demand and in the long run will succeed in collecting some tax. ${ }^{259}$

Globalization allows us to add more jurisdictions to Adams's example-the software engineers work in jurisdiction $\mathrm{E}$, the company's financing subsidiary is in jurisdiction $\mathrm{F}$, the intellectual property resides in jurisdiction $\mathrm{G}$, and the company has customers, but no physical presence, in jurisdictions $\mathrm{H}$ through Z. But Adams's main conclusion-that every jurisdiction with a colorable claim to tax "will in the long run succeed in collecting some tax"-is as applicable today as in 1917. Unless multinationals will be subject to multiple taxation, the question remains how states will resolve their overlapping tax claims. As the U.S. Supreme Court observed, providing an answer resembles "slicing a shadow."260

In the absence of shared conceptions of efficiency or fairness, views regarding the proper division of income remain contested. The difficulty of resolving distributional questions is familiar from domestic law. Even the notion that the burden of paying taxes should be distributed according to ability to pay does not tell us what the tax rates should be. In the domestic context, we use democratic procedures to distribute the tax burden. But no global institution exists that would allow us to democratically resolve the question of how states should divide entitlements to tax international income. Thus, any future compromise by necessity will be constructed from interstate bargaining.

This is not to say that all possible divisions are normatively equivalent or that only politics matters. ${ }^{261}$ But adherence to different theories about what is fair and of how to maximize welfare and whose welfare to maximize lead to different conclusions. Advocates garner support for their preferred outcome when they can point to convincing reasons based in efficiency, advancing justice, or other values. ${ }^{262}$ While efficiency and fairness norms cannot generate precise allocation rules that cover all situations, widely held norms like the benefits principle generate shared intuitions and expectations regarding acceptable allocation

${ }^{259}$ Graetz \& O’Hear, supra note 12, at 1093-94. Modern economists share these views. See references in note 255 supra. Interestingly, in her history of the 1928 League of Nations discussions that led to the first model tax treaty, Sunita Jogarajan recounts an intervention from a Bulgarian delegate, who objected that under the proposed permanent establishment threshold, "tobacco purchasing firms in Bulgaria would not be taxable in Bulgaria." JOGARAJAN, supra note 12, at 246. The Bulgarian delegate's complaint about the failure to capture input values is similar to modern complaints that states cannot tax companies that take advantage of contributions made by users of social media websites.

${ }^{260}$ Container Corp. of America v. Franchise Tax Bd., 463 U.S. 159, 192 (1983) (comparing the arm's-length method to formulary apportionment). See also Ault \& Bradford, supra note 242, at 31 ("[a]ttaching locations" to certain "changes in wealth," for example, those due to "discovery of a new drug formula or new consumer good" "involves arbitrary line drawing, with attendant controversy").

${ }^{261}$ See, e.g., Kane, supra note 7, at 332-39 (providing a positive account of current source rules that draws on the benefits principle and enforceability concerns).

262 See, e.g., Galya Savir, Regulation and TaX in Space (on file with author) (recounting ability of Maltese ambassador Arvid Pardo, by appealing to notions of fairness in negotiations for a regime to govern deep seabed mining, to persuade policymakers from other states to set aside national self-interest). 
bargains. Moreover, once states decide how tax entitlements should be allocated, efficiency, fairness, and administrability will inform how technocrats construct the rules to effectuate the tax bargain.

It is worth emphasizing that the permanent establishment is a political invention. ${ }^{263}$ In the 1920s, a physical presence requirement for taxation made sense. Later, as intragroup transfer pricing ramped up, countries adopted the arm's-length method to counter profit shifting. ${ }^{264}$ Arm's length seemed a reasonable response to a growing problem, and its defects were either unrecognized or regarded as better than the alternatives. Long use and widespread acceptance made our tax rules seem not only stable but well-grounded. Each new generation of tax lawyers, administrators, and policymakers learns its sacred texts-the OECD Model, the Commentary, the Transfer Pricing Guidelines - and tax experts confabulated post-hoc rationalizations for arbitrary allocation rules. ${ }^{265}$ A hundred years later, technical experts decry the invasion of international tax forums by politics. ${ }^{266}$ But questions about how to distribute the gains from globalization are as political today as they were in the 1920 s, and they will be settled-if they are settled-by bargaining.

\section{The Changing Politics of International Tax}

If bargaining over national interests will play a starring role in determining the outcomes of BEPS 2.0, what do states want? This section can only provide a snapshot of what Hugh Ault characterized as a third type of tax competition-the competition to define the distributive rules in a way that maximizes national tax revenue. ${ }^{267}$ Although high-tax developed countries generally share an interest in preserving an allocation system that disproportionately benefits them at the expense of developing countries, important cleavages in the interests of developed countries have emerged in the past two decades. Developed countries like France, whose benefits from the 1920s compromise have eroded, see an opportunity to gain revenue share relative to the United States, but they also face the risk that enlarged taxation by consumer or source states would cause them to lose revenue relative to the developing world, especially China and India.

This section briefly identifies four factors that seem especially important to the negotiations: the emergence of the BRICs (Brazil, Russia, India, China, and South Africa), the rupture in tax relations between the United States and Western Europe, the rise of tax

${ }^{263}$ For the history, see Graetz \& O’Hear, supra note 12.

${ }^{264}$ For detailed history of arm's-length, contrasting the U.S. and OECD approaches from the 1930s to today, see Langbein \& Fuss, supra note 34.

${ }^{265}$ For example, Wei Cui now offers a convincing — albeit post hoc — theoretical basis for digital taxes, namely, that they tax a location-specific rent. Cui, supra note 257. No one knows the fate of digital services taxes, but if they survive, Cui's post-hoc justification could well become part of the standard explanation for a tax whose original motivation was blatantly political and protectionist.

266 See, e.g., Interview with Stack, supra note 183, at 723 ("the politics in Europe are driving bad policy"); Alex Parker, OECD Shouldn't Rush Digital Tax Rules, Ex-Treasury Official Says, Law360 (July 18, 2019) (attributing to former Treasury official Mike McDonald concerns that politics, rather than principle, would drive BEPS 2.0). McDonald said, "Instead of it being the organic process of economic analysis identifying the problem, it is, 'let us come up with economic justifications to support the solutions."” Id. (quoting McDonald).

267 See Hugh Ault, Tax Competition and Tax Cooperation: A Survey and Reassessment, in InTERNATIONAL Taxation in a Changing Landscape: Liber Amicorum in Honour of Bertil Wiman (2019). The other types are competition for (1) business and investment and (2) paper profits to tax. 
unilateralism, and changes in the law and economy of the United States that affect its outlook on tax allocation. ${ }^{268}$

Emergence of the BRICs. Major emerging economies - in particular, China and India - that never agreed to the 1920 s compromise see an opportunity to gain revenue share by reducing the extent to which tax treaties shift revenue away from source countries and toward residence countries. ${ }^{269}$ Criticisms of the distributive outcome of tax treaties are not new. Developing countries, which are disproportionately source countries, long have complained that tax treaties require them to cede too much tax to residence countries. Indeed, states developed the UN Model tax treaty as an alternative to the OECD Model to help counter this shift. ${ }^{270}$ But developing countries have had little success in persuading their developed-county treaty partners to adopt the UN Model. ${ }^{271}$

Rupture between the United States and Europe. Several recent events reflect important cleavages in the interests of European countries and the United States that may affect their ability to display a united front to developing countries seeking a larger share of tax revenue from international commerce.

The United States and European countries found themselves on opposite sides of many BEPS issues, as Bob Stack, the chief U.S. negotiator for BEPS, made clear. ${ }^{272}$ This was perhaps inevitable. U.S. multinationals had stripped European tax bases for decades, a practice overtly facilitated by U.S. law. ${ }^{273} \mathrm{New}$ business conventions, such as third-party manufacturing, warehousing, and delivery enabled nonresident companies to reap significant profits in Europe while treading lightly or not at all on the soil of market states. An office, branch, factory, or store constitutes a permanent establishment, but a web presence does not.

${ }^{268}$ For more on politics, see Christensen \& Hearson, supra note 1.
${ }^{669}$ See, e.g., Jinyan Li, China and BEPS: From Norm-Taker to Norm-Shaker, 69 BulL. INT'L TAX'N (2015); Baistrocchi, supra note 160 . Holding bilateral investment constant, tax treaties shift revenue from source states to residence states as compared with the no-treaty situation. If negotiated between states whose bilateral investment is symmetrical, tax treaties should have little revenue impact—what a state loses in a source capacity, it gains in a residence capacity. But states' bilateral investment is rarely symmetrical, and the more asymmetrical, the more the net-source state loses revenue to the net-residence state. This revenue impact of tax treaties has long been recognized. Dagan, supra note 10. The OECD Model is therefore described as a poor fit for negotiation between rich and poor countries whose bilateral investment flows are very asymmetrical, and the UN Model has provisions that reduce the revenue shift. Despite the potential revenue shift, developing countries would give up source entitlements (which they do under both the UN and OECD Models) because they expect to receive more inbound investment when treaties enter into force, or to gain nonrevenue benefits from treaties, such as closer diplomatic relations with their tax treaty partners.

${ }^{270}$ U.N. Dep’t Of Econ. \& Soc. Affairs, United Nations Model Double Taxation Convention Between Developed and Developing Countries (2011), available at https://www.un.org/esa/ffd/wp-content/uploads/ 2014/09/UN_Model_2011_Update.pdf [hereinafter UN ModeL]. See also Michael Lennard, The Purpose and Current Status of the United Nations Tax Work, Asia-Pacific Tax Bull. 23 (2008).

${ }^{271}$ Yariv Brauner, An International Tax Regime in Crystallization, 56 TAX L. REV. 259, 307 (2003).

272 See also Ryan Finley, EU Unilateralism Calls for Aggressive U.S. Approach, Stack Says, 84 TAx NOTES INT'L 988 (2016) (quoting Stack as saying, "The committee [on fiscal affairs of the OECD] is a European-dominated institution. They have 22 of the 35 members, [and] they are the largest bloc in this new inclusive framework that we have to implement BEPS."). Stack also related that when it became clear that country-by-country reporting would be adopted over U.S. objections, the United States agreed to the measure, negotiating to keep the reports from being publicly released. But the EU Commission announced that it would proceed with EU legislation to make the reports available to the public anyway. Although the EU did not follow through on this proposal, it eroded trust with U.S. negotiators. Id. at 1046 (quoting Stack as saying the action "bordered on bad faith").

273 Bob Stack acknowledged this. Interview with Stack, supra note 183, at 726 ("the only reason you get the wrong answers is because of U.S. cost share rules and because of check-the-box in the United States"). 
The obsolescence of the permanent establishment concept found extreme expression in the technology sector. ${ }^{274}$ Dominance of this sector by U.S. multinationals has meant that Western European countries are increasingly on the losing side of tax treaties with the United States. Social media, internet search, and streaming companies-Facebook, Twitter, Google, Netflix, YouTube-extract huge profits from selling targeted advertisements and subscriptions, but user states cannot tax those profits because the companies avoid creating permanent establishments there. Likewise, companies that provide digital markets to link sellers and customers, such as Amazon, Airbnb and eBay, avoid creating permanent establishments in the states of the seller or the buyer.

Companies' growing ability to avoid permanent establishments has exacerbated the revenue shift caused by tax treaties and widened the set of losing states. ${ }^{275}$ Pascal Saint-Amans, the head of tax for the OECD, observed that " $[\mathrm{t}]$ he Europeans have experienced what it is like to be a developing country. They had clever people coming in, making money, not giving anything back and then leaving." 276 That European countries increasingly felt the sting of the tax-treaty revenue shift divided the interests of the United States and Europe.

Other events reflected growing U.S.-European tensions. For example, the EU Commission's tax state-aid investigations focused on tax rulings that EU states issued to brand-name U.S. companies; these allegedly sweetheart deals allowed U.S. companies to avoid tax. ${ }^{277}$ The EU state-aid rules—which forbid member states from subsidizing private enterprises unless they have permission from the Commission-had been understood to apply to tax subsidies since at least the late 1990s. But the Commission had never investigated member states for tax state-aid that they conferred to particular companies. ${ }^{278}$ The novelty of the investigations combined with what seemed to be disproportionate targeting of U.S. companies through a nontransparent selection procedure elicited a sharp bipartisan rebuke from the Senate Finance Committee ${ }^{279}$ and a tense exchange of letters between the U.S. Treasury secretary and the EU commissioner for competition. ${ }^{280}$ In August 2016, the Commission ignited a firestorm when it assessed a staggering \$14 billion recovery order against Apple, reasoning that all the income that Apple had shifted to the nowhere subsidiaries ${ }^{281}$ should have

\footnotetext{
${ }^{274}$ Ed Kleinbard's discussion of how Starbucks uses transfer prices to shift profits on that most local provision of services-selling hot coffee-shows that we have an economy-wide problem. The Starbucks example shows that profit shifting is not limited to technology companies or to companies with unique intellectual property. See Kleinbard, supra note 58.

275 That the shift was away from source did not necessarily mean than it was toward residence. As discussed in Part I, the international tax regime provides ample opportunity for taxpayers to shift their profits to tax havens or make them disappear completely.

${ }^{276}$ Matt Thomson, Int'l Income Allocation Rules Outdated, OECD Tax Chief Says, Law360 (Feb. 4, 2020).

277 Procedurally, the Commission's case is against the EU member state, but the penalty falls on the company, which has to repay the illegal subsidy. For more on state aid, especially the cases against U.S. multinationals, see Mason, supra note 65.

${ }^{278}$ Instead, the Commission had previously taken issue with entire regimes, such as tax holidays. See id. at 457.

${ }^{279}$ Senate Finance Committee Letter to Treasury Secretary Jacob Lew, Bipartisan Concern Over Targeting of American Firms (May 23, 2016) (noting that "the United States has a stake in these cases and has serious concerns about their fairness and potential impact on the U.S. fisc"). Id. ("EC officials generally have dismissed our concerns"). Id. (noting that four of the five investigations involved U.S. multinationals).

${ }^{280}$ Letter from EU Commissioner of Competition Margrethe Vestager to Treasury Secretary Jacob J. Lew, at 23 (Feb. 29, 2016) (asserting that the state-aid investigations did not discriminate against U.S. companies or violate tax treaties).

281 See discussion in Part I.B.1 supra.
} 
been taxed in Ireland (of all places). ${ }^{282}$ Although both Apple and Ireland have appealed the decision, if enforced, the recovery would represent both the largest tax deficiency in history and the largest ever state-aid penalty. ${ }^{283}$ In a move the Wall Street Journal dubbed "a diplomatic broadside," 284 the Treasury Department issued an extraordinary twenty-five-page white paper arguing that the Commission departed from prior EU law and its own practice in the recent state-aid cases involving U.S. companies. ${ }^{285}$ In another unprecedented move, the United States tried to intervene in the Apple case, but the EU courts held that it lacked standing. ${ }^{286}$ The state-aid cases sent a shock-wave through the international tax community, prompting respected academic Michael Graetz to write an op-ed arguing that to "a U.S. lawyer steeped in the requirements of due process and the rule of law, the process by which these fines were decided doesn't pass the smell test." 287 Bob Stack confirmed that the state-aid investigations soured U.S.-EU relations at the OECD. ${ }^{288}$

The Commission's unsuccessful proposal in 2018 for a digital-services tax further drove the wedge between the United States and Europe. ${ }^{289}$ In response to popular dissatisfaction with corporate tax avoidance, and perhaps to consolidate its own power vis-à-vis the member states, the Commission proposed a new digital tax that was tailor-made for U.S. internet giants, including Airbnb, Amazon, Facebook, Google, and Twitter. ${ }^{290}$ U.S. dominance in technology enabled the Commission to formulate a tax that would almost perfectly target U.S. companies, while exempting nearly all EU companies, even when those companies engaged in the same commercial activities as the targeted U.S. companies. ${ }^{291}$ The EU

${ }^{282}$ The reasons the Commission located the income in Ireland are complex, and they highlight the limits of state aid as an enforcement mechanism for aggressive tax avoidance. For more, see Mason, supra note 20.

${ }^{283}$ Sean Farrell \& Henry McDonald, Apple Ordered to Pay $€ 13$ bn After EU Rules Ireland Broke State Aid Laws, GUARDian (Aug. 30, 2016) (noting that the Apple recovery order was " 40 times the previous record for such a case and the equivalent of the annual budget for Ireland's health service").

${ }^{284}$ Editorial Bd., The EU's Tax Attack on U.S. Business, WALL ST. J. (Aug. 26, 2016).

285 U.S. Dep’t Treasury, The European Commission’s Recent State Aid Investigations of Transfer Pricing Rulings (Aug. 24, 2016).

${ }^{286}$ Case T-892/16, Apple v. Commission, ECLI:EU:T:2017:925, Order of the General Court (Dec. 15, 2017).

${ }^{287}$ Michael Graetz, Behind the European Raid on McDonald's, WaLl ST. J. (Dec. 3, 2015) (concluding that "[a]ttacking multinational corporations-especially U.S. multinationals-for paying too little taxes is a political winner. But at what cost to the rule of law?").

${ }^{288}$ Interview with Stack, supra note 183, at 727 ("if the European institutions are going to say, well, now we're going to take this [state aid] law and say it really always applied and do something again outside the area of multinational cooperation, it undermines the United States' willingness to show up at the OECD table and ... cooperate").

${ }^{289}$ Proposal for a Council Directive on the Common System of a Digital Services Tax on Revenues Resulting from the Provision of Certain Digital Services, COM(2018) 148 final (Mar. 21, 2018) (EU DST proposal).

290 Ruth Mason \& Leopoldo Parada, Digital Battlefront in the Tax Wars, 92 TAX Notes InT'L 1183 (2018) (arguing that unilateral digital taxes may discriminate on the basis of nationality in violation of EU law); Ruth Mason \& Leopoldo Parada, The Legality of Digital Taxes in Europe, 40 VA. TAX REV. (forthcoming 2020).

${ }^{291}$ The Commission adjusted both the taxable revenue streams and the taxable threshold of its proposed digital tax in ways that targeted U.S. companies. For example, the Commission declined to tax fees from subscriptions to digital streaming services. Commentators observed that doing so would have subjected to digital tax not only Netflix, but also the Swedish giant Spotify. See Gary Clyde Hufbauer \& Zhiyao (Lucy) Lu, The European Union's Proposed Digital Services Tax: A De Facto Tariff, Peterson Inst. InT'L Econ. Pol'y Brief 18-15 (June 2018). The proposed tax would have applied only to companies with at least $€ 750$ million in global turnover, and $€ 50$ million in turnover in the EU. These thresholds effectively exempted nearly all EU companies. See European Commission Staff Working Document: Impact Assessment of the Proposed Digital Services Tax, $\operatorname{COM}(2018) 147$ final, at 69 (Mar. 21, 2018). 
proposal failed due to opposition by Ireland and other tech-friendly states, ${ }^{292}$ but it elicited the condemnation of U.S. lawmakers, who argued that it was designed to discriminate against U.S. companies, would undermine the tax-treaty system, create trade barriers, lead to double taxation, and possibly violate trade law. ${ }^{293}$

Although the EU Commission's digital tax proposal did not secure the requisite votes, several large European states, including France, Italy, Spain, and the United Kingdom, passed or proposed similar digital taxes. ${ }^{294}$ In touting these taxes, politicians have not hidden their intent to discriminate against U.S. companies while exempting domestic companies. ${ }^{295}$ The dispute between the United States and France became particularly heated when the U.S. trade representative published a withering analysis concluding that the French tax discriminated against U.S. companies in intention and effect and that the United States would be justified in retaliating with tariffs of up to 100 percent on French goods. ${ }^{296}$ The United States responded with similar threats to other EU countries that adopted or threatened to adopt digital taxes. ${ }^{297}$

Growing tax unilateralism. Digital taxes are only one of several recent unilateral moves. As consensus for the old allocation rules erodes, more countries depart from it. ${ }^{298}$ Some of these departures—such as digital taxes or the Commission's state-aid investigations — seem to target U.S. companies, but others are broader. For example, in the midst of the BEPS negotiations in 2015, the United Kingdom enacted a "diverted profits tax" that penalizes nonresident companies that artificially avoid creating British permanent establishments. ${ }^{299}$ India and Israel developed nexus rules that rely on "significant economic presence" rather than physical presence. ${ }^{300}$ Tax treaties bar some, but arguably not all, of these rules. ${ }^{301}$

Several observations are worth making about these unilateral measures. First, they reflect growing dissatisfaction—including among developed states — with the permanent establishment requirement in tax treaties. Second, because these proposals typically raise little

292 Patrick Smyth, Netherlands and Luxembourg Join Ireland as Wary of Digital Tax, IRISH Times (Mar. 23, 2018).

${ }^{293}$ Letter from Sens. Orrin Hatch and Ron Wyden to President Donald Tusk and President Jean-Claude Juncker (Oct. 18, 2018).

${ }^{294}$ Editorial Bd., France Starts a Digital Tax War, WaLl ST. J. (July 16, 2019); William Mauldin, U.S. Launches Probe of French Digital Tax, WaLl ST. J. (July 10, 2019).

295 See, e.g., Office of the U.S. Trade Rep., Notice of Determination and Request for Comments Concerning Action Pursuant to Section 301: France's Digital Services Tax, Docket No. USTR-2019-0009 (2019) (detailing evidence of discriminatory intent in the French digital tax, including repeated references by the French finance minister to the "GAFA tax" for Google, Amazon, Facebook, Apple). See also Mason \& Parada, supra note 290, at 1192 (evidence from Spain and Austria).

296 Office of the United States Trade Representative Ambassador Robert E. Lighthizer, Report on France's Digital Services Tax Prepared in the Investigation Under Section 301 of the Trade Act of 1974

${ }^{297}$ Larry Elliot, UK to Press Ahead with Digital Tax Despite U.S. Pressure, Javid Insists, Guardian (Jan. 22, 2020) (describing U.S. threats of retaliation for digital taxes).

298 See Lilian V. Faulhaber, Taxing Tech: The Future of Digital Taxation, 39 VA. TAx Rev. 145, 156-66 (2019) (detailing a broad range of unilateral tax measures).

299 OECD, Tax Challenges Arising from Digitalisation: Interim Report 149-55 (2018). Australia adopted a similar rule based on the British model. Id.

${ }^{300} \mathrm{Id}$. at $137-38$.

${ }^{301}$ Tax treaties address income taxes (and taxes similar to income taxes); they do not cover turnover taxes. As a result, states may, without violating tax treaties, apply turnover taxes to nonresident companies that lack a permanent establishment in the source state. Georg Kofler \& Julia Sinnig, Equalization Taxes and the EU's Digital Services Tax, 47 Int'l Tax Rev. 176 (2019) (concluding that tax treaties do not bar digital taxes). 
revenue, ${ }^{302}$ they must aim at other goals. One possibility is that they respond to voter displeasure with corporate tax avoidance, and in particular corporate tax avoidance by U.S. multinationals. Another possibility is that such taxes aim to convince the United States, which has opposed efforts to renegotiate tax entitlements, to take seriously complaints about the obsolescence of tax treaties. Thus, France promised to repeal its digital services tax if states reach a new allocation deal at the OECD; ${ }^{303}$ France even promised to refund digital taxes to U.S. companies upon reaching a new deal. ${ }^{304}$

By threatening to use new instruments outside the tax treaty framework to impose tax on U.S. companies, the EU and other countries have expressed their willingness to depart from international tax's most sacred norm - that companies should not pay tax twice. Such threats to depart from the international consensus have been at least partially effective in bringing the United States to the bargaining table. ${ }^{305}$ OECD tax chief Pascal Saint-Amans seized on impending unilateralism to persuade countries to compromise. He recently warned, "There's no plan B. There is plan C, and C is for chaos if we don't reach agreement."306 Even representatives of the United States, the world's staunchest advocates for maintaining the status quo, envision the possibility of fundamental rupture. Chip Harter, deputy assistant secretary of the Treasury for international tax policy, recently observed that if countries cannot agree on how to allocate income, "we will be in a world that threatens chaos."307 Unilateral measures thus have been important because, in addition to motivating the United States to participate in allocation negotiations, they motivate multinationals to lobby their own governments to reach a compromise on a stable distribution that would avoid double tax. ${ }^{308}$

Changes in the United States. Because the United States has a disproportionate share of multinationals, the proliferation of unilateral actions will affect U.S. companies disproportionately. As a result, the United States has a special interest in preventing unilateral actions that could result in double tax for its multinationals, thereby undermining their competitiveness. Additionally, any shift in revenue from residence to source may be expected to result in a loss for the United States, a major residence state. But significant domestic legal and economic changes have made the United States more amenable to international tax changes.

302 See, e.g., Mason \& Parada, supra note 290, at 1190 (noting the Commission's estimate that an EU-wide digital tax would raise less than $\$ 6$ billion annually). Tax treaties preclude countries from applying their new nexus rules to companies that reside in their tax-treaty partners, and countries typically have tax treaties with their largest trading partners.

$303 \mathrm{Id}$

${ }^{304}$ Liz Alderman, Jim Tankersley \& Ana Swanson., France and U.S. Move Toward Temporary Truce in Trade War, N.Y. Times (Jan. 21, 2020).

305 This account is consistent with the notion that a single country, by going it alone, can induce cooperation from an otherwise reluctant state. See Azam, supra note 1, at 525-29 (discussing work of Stephen D. Krasner and considering the United States as a go-it-alone actor in international tax). On digital tax and state aid, France and the EU Commission, respectively, would be the go-it-alone actor.

${ }^{306}$ Stephanie Soong Johnston, On the Brink of a New Tax World Order, or Chaos?, TAx Notes (Jan. 2, 2020).

307 Stephanie Soong Johnston, U.S. Senators Warn EU Digital Taxes Undercut OECD Progress, 93 TAX NoTES INT'L 578 (Feb. 4, 2019).

${ }^{308}$ Not limiting its responses to negotiations at the OECD, the United States threatened retaliation against France and other countries for digital taxes. See, e.g., Ana Swanson, U.S. Announces Inquiry of French Digital Tax that May End in Tariffs, N.Y. Times (July 10, 2019). 
In the early twentieth century, the United States was a clear capital exporter. ${ }^{309}$ This posture helps explain the 1920s tax treaty framework, which shifted tax revenue from source to residence. Over the course of the twentieth century and into the twenty-first, however, the United States became not only one of the largest capital importers, but also one of the world's largest and richest consumer markets. ${ }^{310}$ These shifts are important for current negotiations. If the United States can minimize its revenue losses from an allocation shift because the new system reassigns tax share from residence states to consumer states, then the United States, which was a large winner from the 1920 s compromise, should have fewer objections to the change. This is one reason why the United States insists that any solution negotiated at the OECD cannot be limited to the digital sector. That insistence also ensures that other traditional residence countries share the expected revenue losses from a change in the permanent establishment requirement. The U.S. argument for system-wide, rather than digital-only, reforms may find support from other countries with large markets, including China and India. ${ }^{311}$

Major domestic legal reforms in 2017 have also changed international tax strategy for the United States. Under pre-2017 law, foreign tax avoidance by U.S. multinationals ultimately redounded to the U.S. fisc, although the tax was deferred until repatriation. The 2017 corporate-tax-rate reduction was funded, in part, by a partial elimination of deferral of tax on the foreign income of foreign subsidiaries of U.S. companies. In place of deferral, the United States substituted either permanent exemption or current U.S. taxation at about half the newly lowered U.S. rate. ${ }^{312}$ Both lowering the corporate tax rate and exempting certain foreign-source income have the effect of reducing the revenue incentive for the United States to oppose source taxes by other countries. ${ }^{313}$ The 2017 tax reform therefore had the unintended consequence of making the United States more willing to negotiate allocation changes.

\section{G. Predictions}

Despite the dramatic changes to international tax reflected in BEPS and detailed in Part III, in the Introduction to this Article, I described the end of BEPS 1.0 as an inflection point: the future could involve more multilateral cooperation, more unilateralism, or the persistence of a predominantly bilateral regime. While it is too soon to draw conclusions on the direction of international tax, this Subpart speculates as to the durability of the various BEPS reforms.

The thirty-seven OECD countries can no longer claim an exclusive role in international tax policymaking now that the rest of the G20 has become accustomed to having a voice. At the same time, however, BEPS firmly solidified the role of the OECD as an institution in tax policymaking - including by accommodating more involvement by the non-OECD G20 countries. The current difficult negotiations over allocation represent a risk for the institution,

\footnotetext{
309 See Dagan, supra note 10, at 988 n. 105.

${ }^{310}$ OECD, International Direct Investment Statistics Yearbook (2018) (United States is the world's largest capital importer, including portfolio flows); World Bank, Households and NPISHs Final Consumption Expenditure, at https://data.worldbank.org/indicator/NE.CON.PRVT.CD (indicating the United States as top consumer market in the world).

${ }^{311}$ Keith Rapoza, India Poised to Be Third Largest Consumer Economy, Forbes (Mar. 21, 2017) (listing China and India as the world's largest consumer markets after the United States).

312 IRC $\$ \$ 245 \mathrm{~A}$ (effective exemption); 951A (minimum taxation of foreign income).

313 There is much more to the impact of the Tax Cuts and Jobs Act of 2017 than I can relate here.
} 
however. If states cannot agree on a more stable solution, the OECD as an institution may see its authority and role diminish.

Acceptance of full taxation as an international tax norm, although accelerated by BEPS, has been incremental and is likely durable. Although the Multilateral Instrument holds great promise, because it leaves bilateral treaties intact, it is cumbersome and raises complicated legal issues. ${ }^{314}$ It seems likely that states will incorporate the Instrument's provisions into their bilateral treaties as they renegotiate them, over time obviating the need for the Multilateral Instrument. Thus, unless states adopt truly multilateral provisions that cannot be incorporated into bilateral treaties, such as rules to resolve source-source conflicts, we might expect a reversion to nearly exclusive bilateralism in tax treaties. ${ }^{315}$ At the same time, however, certain BEPS benefits-coordinated fiscal fail-safes, other coordinated anti-abuse rules, and disclosure and information-sharing regimes ${ }^{316}$ - cannot be secured exclusively through bilateralism, so we should expect them to endure as multilateral coordinated measures.

As noted above, the fate of the Inclusive Framework is uncertain. It could develop into a highly effective organization that has only a limited scope, like the Global Forum on Tax Transparency, or it could deepen into a more meaningful policymaking body with a role in international tax policy.

It is worth repeating that, as with the no-double-tax norm, the full-tax norm cannot be fully specified without an agreed distributive rule that determines where income will be taxed. The growing acceptance of full taxation has thus led to a chaotic situation in which multiple states seek to fill perceived tax vacuums. The risk that double taxation could reemerge motivates cooperation among states. ${ }^{317}$ The twin aims of full taxation and avoiding double taxation necessitate more international cooperation than did a no-double-tax norm alone. Avoidance of double taxation requires only that either the source state or the residence state recede. Full taxation, in contrast, requires not only that some states recede, but also a coordinated answer regarding which state or states will affirmatively tax.

Nevertheless, predicting the outcome of the current tax allocation dispute is hazardous at best. The allocation negotiation is zero-sum, or nearly so, its surplus arises from reducing risks of double taxation, compliance costs, and uncertainty. U.S. representatives to the OECD hope to keep the aspirations of the project as narrow as possible, and recently they have even argued that any new rules that give tax entitlement to market jurisdictions should function as safe harbors, rather than mandatory rules. Given the difficulties of the negotiation and the reluctance of other OECD members-particularly Western European states-to join source states' call for wholesale reform (as opposed to reform that applies to digital companies only), possible outcomes include the modest reforms advocated by the United States, or no

${ }^{314}$ See, e.g., Robert Stack, 22d Annual David R. Tillinghast Lecture on International Taxation (NYU School of Law), YouTuBE (Sept. 22, 2017), at https://www.youtube.com/watch?v=zcdeiTL-gFE (recounting some of the difficulties of using a multilateral treaty to update bilateral treaties).

${ }^{315}$ As discussed above, such bilateralism also suits powerful countries. See text accompanying note 51 supra.

316 These include country-by-country reporting, information-sharing about tax rulings, transfer-pricing documentation, disclosure of aggressive tax-planning positions, and peer review of harmful tax practices and dispute resolution procedures.

317 OECD Work Program, supra note 237, at 7 (explaining BEPS 2.0 as motivated by concern among the Inclusive Framework countries that proliferation of unilateral measures will "adversely impact global investments and growth"). 
reform at all combined with tolerance for digital taxes. Such a compromise would allow the United States and Western Europe to reunite to fend off claims by source states to tax multinationals' income in the absence of permanent establishments. The narrowness of digital taxes as a solution would help address popular demands in Western European countries to tax U.S. companies, while at the same time limiting to only a single sector any revenue shifts and opposition lobbying efforts. If the United States and the Western European countries cannot agree on a separate compromise, however, they may not be able to overcome claims by source countries to a larger slice of the pie.

\section{Conclusion}

Throughout the twentieth century, states oversatisfied the norm against double taxation, accommodating significant nontaxation of corporate income. If the international tax regime did not manage to assign an item of income to be taxed, that gap caused no special alarm. The twin pressures of financial crisis and voter discontent motivated states to embark on the BEPS Project to fix tax gaps and other corporate tax-avoidance issues. Notwithstanding the modest formal recommendations of the BEPS Project, and contrary to academic criticism, this Article argues that BEPS both reflected and achieved fundamental change in the decisionmakers, agenda, norms, and legal forms of international tax.

While confirming and effectuating seismic shifts in international tax, the BEPS Project shored up old and disputed allocation rules using innovative instruments of international law, including the Multilateral Instrument and fiscal fail-safes. The point of BEPS was to grow the revenue pie by shutting down corporate tax avoidance- not to re-slice the piebut it was unrealistic to think that the states could pursue full taxation while remaining indifferent to which state received the tax. This Article thus argues that one of the most important - if underappreciated - outcomes of BEPS is that by increasing the salience of distributive issues and creating an inclusive forum for negotiating distributive outcomes, BEPS made it more, not less, likely that states would seriously reconsider longstanding distributive questions.

Now is a crucial moment for international tax. Over one hundred countries are locked in a complex negotiation to decide how states should divide the entitlement to tax income from cross-border economic activities. BEPS provided a forum for negotiation-the Inclusive Framework-and populated it with representatives of developing countries nurturing long-ignored grievances about the prior distribution. Although we will not know the results of BEPS 2.0 for some time, this Article considered factors that will influence potential outcomes, including a widening rift between the United States and Europe and recent changes in U.S. tax law. It concluded that national self-interest will be the most important driver of any resolution of the allocation question, but efficiency, fairness, and administrability concerns will shape resulting rules.

Despite dire warnings of impending chaos, however, deviations from the 1920s compromise have been modest so far, consisting of very narrow digital taxes, changes to domestic nexus rules that do not affect companies resident in tax-treaty partners, and stepped up anti-abuse enforcement. This modesty suggests that commitments to minimizing double taxation though coordinated solutions remain strong. 
It is also worth remembering that, although we lack shared values that could guide us to a stable new distributive outcome, we never shared such values. The international tax regime has always represented a negotiated bargain among states over how to divide the spoils of globalization. Appeals to fairness, efficiency, and administrability informed this bargain, even though the architects of our current tax system disagreed about how to weigh them. Through incrementalism in the twentieth century and paroxysms in the twenty-first, countries have built consensus for a system in which all of company's income should be subject to tax once. Next, they will decide how to share that tax. 